\title{
Forecast of Agricultural Calendar for Maize (Zea Mays) from Global Circulation Model in the Ruzizi Area (DRC)
}

\author{
Mutalemba Ntole Romain,", Muhigwa Jean Berckmans², \\ Katcho Katcho Karume ${ }^{3}$, Mukengere Bagula Espoir ${ }^{4,5}$ \\ ${ }^{1}$ Engineering in Agricultural, Evangelical University in Africa, DR Congo \\ ${ }^{2}$ Department of Biology, Faculty of Sciences, Bukavu Official University, DR Congo \\ ${ }^{3}$ Faculty of agriculture and Environmental sciences, Evangelical University in Africa, DR Congo \\ ${ }^{4}$ College of Agricultural and Environmental Sciences (CAES), Makerere University, Uganda \\ ${ }^{5}$ Faculty of Agriculture and Environmental Sciences, Soil Management and Geoinformatic Unit, \\ Evangelical University in Africa, DR Congo
}

Copyright $\bigcirc 2018$ by authors, all rights reserved. Authors agree that this article remains permanently open access under the terms of the Creative Commons Attribution License 4.0 International License

\begin{abstract}
The world is facing several major challenges that regarding answer to the current economic crisis and the development of appropriate strategies to mitigate the adverse effects of climate change. The objective of the study is to identify climate risks for maize and the development of an agricultural calendar from a global circulation model. From meteorological data, an agro-climatic analysis was performed during the period 1995-2013 and a forecast from 2015 to 2045 has been done. The results showed that maize is facing major agro-climatic risks from the shortening of the vegetative growth period consecutive to a screeching halt rains before the end of the rainy season which is one of the major agro-climatic constraints. From predicting Echam-5 model, the agricultural calendar was adjusted to avoid the drop in rainfall observed in October and plan the sowing period at the end of October instead of September.
\end{abstract}

Keywords Models, Maize, Climate Change, Forecast

\section{Introduction}

\subsection{Background}

Maize is vital for the food security of many vulnerable populations (Bruinsma, 2009). It is also an important crop for its impact in the economy as a commodity. As any other crop, maize production is sensitive to climate, and climate is changing in ranges that are expected to alter maize crop efficiency (Adams et al., 1998; FAO, 2012). It is therefore important that we understand how maize growth will be affected by changing climate factors. Given that future climate may be different in many maize cropping regions from what has ever been observed, especially as far as temperature and $\left[\mathrm{CO}_{2}\right]$ are concerned, process-based models are therefore essential tools to address that question.

In the Ruzizi plain maize is the most cultivated cereal. The maize growing area accounts for three-quarters of the total area of the province of South Kivu. Since the 2000s, the area planted with maize has been steadily increased. The emergence of improved seed producers and seed farms is strongly demanded both within and outside the country, including neighboring countries such as Rwanda and Burundi. Today, Maize enters the culinary habits and especially becomes a raw material for the breweries. It is mainly intended for self-consumption and provides variable cash income depending on the farm. Corn residues are also an important source of animal feed. Finally, from a food-based crop, maize has gradually become a cash crop with greater receptivity to technical improvements. However, maize cultivation is an agricultural activity sensitive to the vagaries of climate and weather (DGPER, 2010)

The very heavy rains and the flooded fields everywhere in the hamlets and villages of Ruzizi area are the main topics of farmers' conversations. Finding water standing in their fields after heavy rains are common; their fields were actually flooded was less so. Their main concerns are the young age of their crops, paddy, and maize, and the already retarded growth due to a long drought in the past period.

The farmers, whose fields were heavy black clay soil, feared possible damages to their crops. That turned out to be the case. The roots and stems of the 30-40-days-old 
maize decayed. Their leaves turned yellow, as did the paddy leaves. Other crops, such as chili, were also badly affected (Winarto and Stigter 2011).

These surprising facts were examples of a real risk resulting from an increase of climate variability and climate-related extreme events as consequences of climate change (see OXFAM 2009). The question remains, therefore, how to help farmers respond better to these phenomena, which they are currently unable to cope with. Direct experience and empirical observations are the main means of learning in the local domain of knowledge. Without directly seeing, feeling, and experiencing the phenomena they encounter in daily life, they will not have any confidence or belief in their own or other people's interpretation and sayings (see Winarto 2004; 2010).

Phenomena of climate change and variability cannot be observed directly by farmers themselves, and the impact on farmers' lives cannot easily be predicted or anticipated. On the other hand, farmers can rely on their memories and recent experience to develop their expectations of the future, and this shapes their knowledge of climate phenomena and their understanding of climate information (see Roncoli et al. 2003, 181) [1]. As also argued by Peterson and Broad $(2009,78)$ [2].

\subsection{Problem Statement}

While the seasonal variability of weather is a major source of production risks (Fraisse et al., 2006), significant benefits have arisen from the use of seasonal climate forecasts. Nonetheless, it is now widely accepted that the existence of predictable climate variability and impacts is necessary but not sufficient to achieve effective use of seasonal forecasts (Podesta et al., 2002). The realization of such benefits has been shown to require deliberate efforts to design and implement effective mechanisms for using climate information in the service of society. Several empirical studies have identified theoretical and practical obstacles to the use of climate information and forecasts (for example, Mjelde et al., 1998; Stern and Easterling, 1999; Agrawala et al., 2001).

Weather plays an important role in agricultural production. It has a profound influence on crop growth, development and yields; on the incidence of pests and diseases; on water needs; and on fertilizer requirements. This is due to differences in nutrient mobilization as a result of water stresses, as well as the timeliness and effectiveness of preventive measures and cultural operations with crops.

Occurrences of erratic weather are beyond human control. It is possible, however, to adapt to or mitigate the effects of adverse weather if a forecast of the expected weather can be obtained in time. Rural proverbs abound in rules of thumb for anticipation of local weather and timing of agricultural operations in light of expected weather. Basu (1953) found no scientific basis for anticipation of weather in many of the popular proverbs and folklore. In a recent study, Banerjee et al. (2003) arrived at conclusions similar to that of Basu (1953). The proverbs and local lore show, however, that farmers have been keen to know in advance the likely weather situations for crop operations from time immemorial. Agronomic strategies to cope with changing weather are available. For example, delays in the start of crop season can be countered by using short-duration varieties or crops and thicker sowings. Once the crop season starts, however, the resources and technology get committed and the only option left then is to adopt crop-cultural practices to minimize the effects of mid-seasonal hazardous weather phenomena, while relying on advance notice of their occurrence. For example, resorting to irrigation or lighting trash fires can prevent the effects of frosts. Thus, medium range weather forecasts with a validity period that enables farmers to organize and carry out appropriate cultural operations to cope with or take advantage of the forecasted weather are clearly useful. The rapid advances in information technology and its spread to rural areas provide better opportunities to meet the rising demand among farmers for timely and accurate weather forecasts.

Otherwise, the region of the Ruzizi plain is located in an agropastoral zone characterized by a recent strong anthropization. Nearly $90 \%$ of the population practices subsistence agriculture (KITAKYA, 2007). This agriculture, vital for the local population, is closely dependent on the rainfall regime and its excesses, which affect agricultural yields at different scales of time and space. Unfortunately, the rainfall characteristics of these rainfall events are poorly studied as they influence the evolution of local ecosystems.

All these phenomena, supposedly extreme by the local population, are not argued objectively on scientific grounds. NEW et al. (2006) and AGUILAR et al. (2009) state that there is a lack of information on trends in rainfall and climate extremes in many regions across developing countries. SOLOMON et al. (2007) and OZER et al. (2009) also estimate that rainfall indices are still too little studied in the DRC and sub-Saharan Africa in general.

MAHÉ (1993) points out that the equatorial zone is a highly contrasted hydrological environment and that it remains linked to the complexity of the ocean-atmosphere system that generates precipitation, a complexity due to its position straddling the two hemispheres. Despite the often dramatic consequences of rainfall fluctuations on agriculture and the environment in the Ruzizi plain, its variability remains poorly known, as are the extreme values in its chronological series. On the other hand, it should be noted that the strong anthropization in the Ruzizi plain area by the presence of refugees followed by a significant degradation of natural resources would only accentuate this climatic variability and / or its impacts in the region.

It is therefore necessary to carefully analyze the seasonal 
cycle of rainfall. Indeed, the interest of this type of study lies in the fact that extreme events could become more frequent due to global warming (HOUGHTON et al., 2001) and that it should be considered now. There is currently a strong scientific interest in the field of climatic extremes because they show some important non-linearities and their economic and social consequences on human activity are potentially (NAVEAU et al., 2005).

The question of the effects of anthropogenic climate change on Climatic conditions could only be approached relatively recently, due to the need to develop appropriate methodological tools. The analysis of their results could make it possible to understand how ecosystems (and socio-ecosystems) react to rare but extreme environmental disturbances. In the Ruzizi plain, in recent years, Early in the dry seasons, even if not very marked.

It is therefore understandable that any disturbance of the hydrological regime may in the short term Vulnerable populations already facing water supply problems. As anthropization marks its pace and is growing to the extent that it can now be seen in the Ruzizi plain, vulnerability may increase. Early warning attention should be given to the potential risk in the event of a change in rainfall patterns and, consequently, to the hydrological regime which will require the rehabilitation of the ever-changing socio-ecosystems. This implies an understanding of the rainfall regime in the context of an increase in the rapid demography of the Ruzizi plain is not accompanied by appropriate adjustments, particularly in the field of water management in the broad sense of the term. This study therefore deals with a characterization of the rainfall events, temperature and evapotranspiration of the Ruzizi plain, the prediction of the irrigation schedule. Thus, time series at different time steps have been established. The results of this study will be able to find a direct application at the local level, particularly in the manifestations of climatic phenomena, the occurrence of floods and in the context of activities related to agriculture in the Ruzuzi plain.

\subsection{Research Issues}

How climatological factors, in particular, the importance and temporal distribution of precipitation, temperature, evapotranspiration, have an effect on the agricultural calendar, growth and yield of maize in the Ruzizi?

\subsection{Objectives}

- To analyze the climatic factors in particular distributions of rainfall, temperature and evapotranspiration and their effects on the cycle of maize.

- Making a choice of climate model which will be used for the adjustment of the agricultural calendar for maize.

\section{Literature Reviews}

In human history, the need to understand climate change has never been more urgent and important than in the 21 st century, especially in tropical areas where deforestation and extinction of species are relatively more important and living conditions, More precarious (Bush and Flenley, 2007). These phenomena are even more acute in Africa where deforestation is very important. The importance of temporal variability in Africa is due to the fact that climatic parameters, which are supposed to vary over time due to the global seasonal cycle of the planet, also show different trends in different regions. Understanding and predicting these annual, decadal or multi-decadal variations in the recent past has become a challenge for African climate specialists (AMMA ISSC, 2005, Janicot et al., 2008). The development of methods for the prediction of climatic variations over the long term has grown prodigiously (Folland et al., 1991, Stockdale et al., 1998, Washington and Downing, 1999). But this did not identify the root causes of the drastic decline in rainfall in Africa (Rowell et al., 1995, Xue and Shukla, 1998).

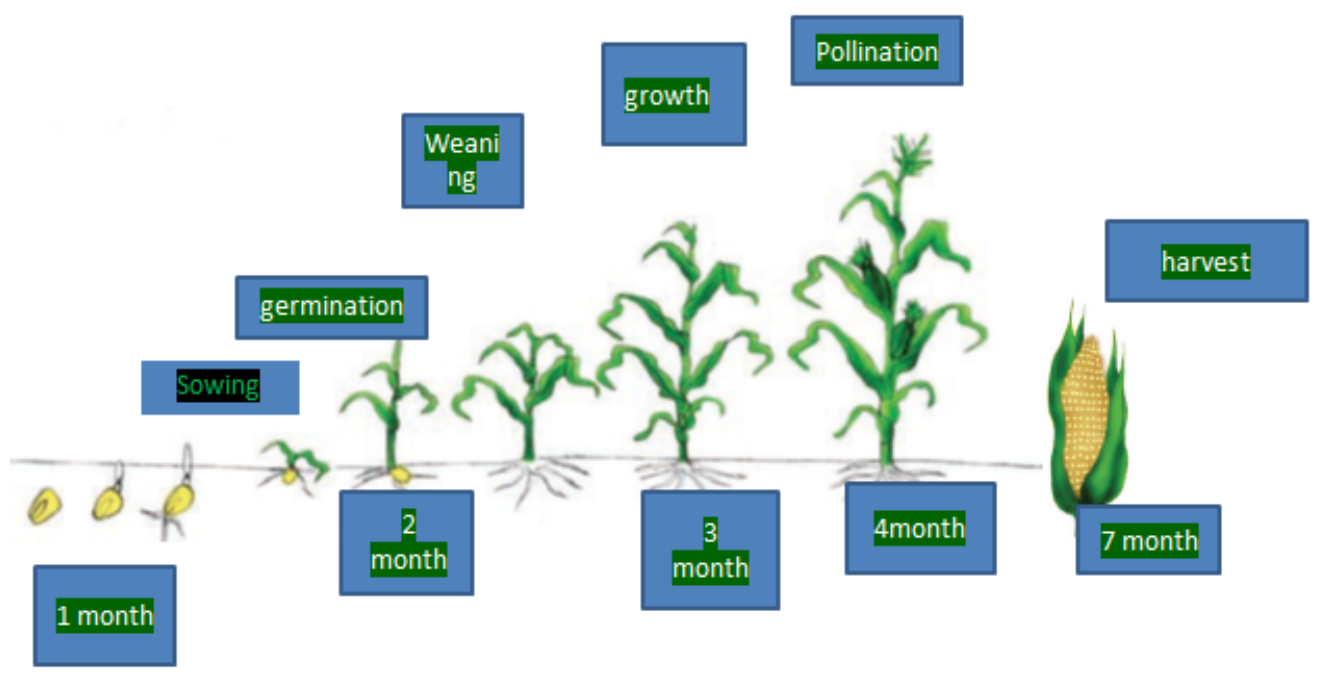

Figure 1. Development of the belated variety of the Maize 


\subsection{Definitions of Climate, Climate Change and Climate Variability}

This sub-section briefly explains the difference between climate, climate change and climate variability and shows the influences of weather producing system on long rainy season in Ruzizi area.

Climate: This is the long-term average weather conditions (usually taken over a period of more than 30 years as defined by the World Meteorological Organization, (WMO) of a region including typical weather patterns such as the frequency and intensity of storms, cold spells, and heat waves (IPCC, 2007b).

Climate Change: Climate change in IPCC usage refers to a change in the state of the climate that can be identified (e.g. using statistical tests) by changes in the mean and/or the variability of its properties and that persists for an extended period, typically decades or longer. It refers to any change in climate over time, whether due to natural variability or as a result of human activity. This usage differs from that in the United Nations Framework Convention on Climate Change (UNFCCC), where climate change refers to a change of climate that is attributed directly or indirectly to human activity that alters the composition of the global atmosphere and that is in addition to natural climate variability observed over comparable time periods (IPCC, 2007b, WMO, 2014).

Climate Variability: Variations in the mean state and other statistics (such as standard deviations, the occurrence of extremes, etc.) of the climate on all temporal and spatial scales beyond that of individual weather events. The term is often used to denote deviations of climatic statistics over a given period of time (e.g. a month, season or year) from the long-term statistics relating to the corresponding calendar period. In this sense, climate variability is measured by those deviations, which are usually termed anomalies. Variability could be due to natural internal processes within the climate system (internal variability), or to variations in natural or anthropogenic external forcing (external variability) (IPCC, 2007b, WMO, 2014). 6

A key difference between climate variability and change is in persistence of anomalous conditions. For instance, an event or sequence of events occurs that has never been witnessed before (or recorded before), such as flood or drought. If such a season does not recur within the next 30 years, we would call it an exceptional year, but not an indication of change (WMO, 2014).

The Intergovernmental Panel on Climate Change (IPCC) (2001) defines climate change as a statistically significant change in the average state of the climate or in its persistent variation over a long period of time (decades or more). Under the terms of Article 1, paragraph 2, of the United Nations Framework Convention on Climate Change (UNFCCC) (1992), climate change refers to "climate changes that are attributed directly or indirectly to human activity that alters Composition of the global atmosphere and in addition to the natural variability of the climate observed in comparable periods ".

\subsection{Modified Functioning Ecosystems}

Atmospheric carbon is the essential component of the process of photosynthesis, which governs the growth of plants. A dubbing of the carbon sequester in carbon dioxide leads in theory to an increase in photosynthesis, a decrease in the transpiration of the plants and, consequently, an Increase in the biomass produced and potential yields for plants of agricultural interest. The efficiency of converting light energy into biomass and water efficiency are increased, so the potential productivity of plant cover is increased.

This positive response of photosynthesis to a carbon enrichment of the atmosphere depends, however, on different factors. The type of carbonated metabolism, temperature and water availability interferes with the increase in photosynthesis consequent on an increase in the content In carbon, for example, whereas $\mathrm{C} 3$ plants (rice, wheat, beet, pea, ect), which predominate in temperate zones, strongly respond to an increase in atmospheric carbon tensor in the considered concentration range, Of $\mathrm{C} 4$ plants (sorghum, sugar cane) has an enrichment of the atmosphere is very low in excess of 400 parts per million, current content of the atmosphere (Malezieux, 2004).

Corn is a demanding water plant. In addition, it is more sensitive to drought (Sarr et al., 1999) than other dry cereals such as millet and sorghum. The water requirements of maize increase with cycle length and type of climate. Depending on climatic conditions, it takes between $400 \mathrm{~mm}$ and $800 \mathrm{~mm}$ of well distributed rain to close its cycle with a temperature sum of 1500 to 1800 degree days (Doorenbos and Kassam, 1980). However, excess water can cause Root rot and asphyxia of maize plants. Corn yields depend more on the availability of water resources during the critical phases of development than the total cumulative rainfall over the entire cycle (Robelin, 1963).

\subsection{Effects of Climate Change on the Agricultural Sector}

If the biology of plant and animal species is disrupted, their dynamics, interaction, equilibrium and ultimately their geographical distribution are likely to change. These changes will affect wild species, crop species, but also pests and diseases Natural ecosystems, subject to a change in species balance and increased competition with agriculture, may deteriorate or even disappear in fragile areas, such as in some estuaries, deltas and lagoons subject to the rise of the sea level (Malézieux, 2004).

\subsection{Direct Effects on Yields: Rainfed Crops and Irrigated Crops}

Changes in rainfed crop yields arise only from changes 
in precipitation and temperatures; In irrigated crops, they come only from changes in temperature. In developing countries, yield reductions predominate for most crops without $\mathrm{CO}_{2}$ fertilization.

Irrigated wheat and rice are hit particularly hard. On average, yields are less affected in developed countries than in developing countries. In fact, in developed countries and for only a few crops, climate change can even lead to higher yields. In the calculation of projections, the East Asia and Pacific region includes both largely temperate China and tropical South-East Asia, masking differences in Effects of climate change specific to these two regions with different climate.

In China some crops behave reasonably well because future high temperatures are favorable where current temperatures are close to the low threshold of the optimum temperature range for these crops. The yields of important crops of Asiedu South-East fall substantially in both scenarios, except in case of efficient $\mathrm{CO}_{2}$ fertilization in farmers' fields.

South Asia is hit particularly hard by climate change. For almost all crops, this is the region with the greatest drop in yield. With $\mathrm{CO}_{2}$ fertilization, yield reductions are lower, and in some of these regions, there are some increases in yield compared to 2000 (Gerald C, Nel et al., 2009). [11]

\subsection{Indirect Effects: Irrigated Crops}

Climate change will have a direct impact on the availability of water for irrigated crops. Domestic renewable water resources (IRW) are water available from precipitation. Both climate models show more precipitation on land than it would be without climate change.

In the NCAR scenario, all regions show an increase in IRW. In the CSIRO scenario, the average increase in IRWs is lower than in the NCAR, with a decline of around $4 \%$ for the Middle East and North Africa regions and sub-Saharan Africa. In addition to changes in precipitation, higher temperatures caused by climate change increase crop water requirements. The ratio of water consumption to needs is called IWSR (reliability of irrigation water supplies). The lower this ratio, the more the water deficit weighs on the yield of irrigated crops. In the developing country group, the IWSR improves in the NCAR scenario but worsens in the CSIRO scenario. However, the effects of climate change vary greatly across regions (Gerald et al, 2009).

\subsection{The SRES Emissions Scenarios}

A1. The A1 storyline and scenario family describe a future world of very rapid economic growth, global population that peaks in mid-century and declines thereafter, and the rapid introduction of new and more efficient technologies. Major underlying themes are convergence among regions, capacity building and increased cultural and social interactions, with a substantial reduction in regional differences in per capita income. The A1 scenario family develops into three groups that describe alternative directions of technological change in the energy system. The three A1 groups are distinguished by their technological emphasis: 17

- Fossil intensive (A1FI)

- Non - fossil energy sources (A1T), or

- Balance across all sources (A1B)

(balanced is defined as not relying too heavily on one particular energy source, on the assumption that similar improvement rates apply to all energy supply and end use technologies).

A2. The A2 storyline and scenario family describe a very heterogeneous world. The underlying theme is self-reliance and preservation of local identities. Fertility patterns across regions converge very slowly, which results in continuously increasing population. Economic development is primarily regionally oriented and per capita economic growth and technological changes are more fragmented and slower than in other storylines.

B1. The B1 storyline and scenario family describe a convergent world with the same global population, that peaks in mid-century and declines thereafter, as in the A1 storyline, but with rapid change in economic structures toward a service and information economy, with reductions in material intensity and the introduction of clean and resource-efficient technologies. The emphasis is on global solutions to economic, social and environmental sustainability, including improved equity, but without additional climate initiatives.

B2. The B2 storyline and scenario family describe a world in which the emphasis is on local solutions to economic, social and environmental sustainability. It is a world with continuously increasing global population at a rate lower than $\mathrm{A} 2$, intermediate levels of economic development, and less rapid and more diverse technological change than in the $\mathrm{B} 1$ and $\mathrm{A} 1$ storylines. While the scenario is also oriented towards environmental protection and social equity, it focuses on local and regional levels (IPCC, 2000).

\subsection{Climate Change in Facing to Agricultural Calendar in Different African Regions}

The analysis of the annual cumulative rainfall of the 1979-2008 series showed that in 80 years the cumulative rainfall is still $\geq 620 \mathrm{~mm}$ in the Sudano-Sahelian zone and can even reach values of more than $900 \mathrm{~mm}$ in the Sudanian zone. Doorenbos and Kassam (1980) showed that the total water requirements of maize varied between 500 and $800 \mathrm{~mm}$ of rainfall. In Burkina Faso, they range between $415 \mathrm{~mm}$ in the Sudanian zone and $544 \mathrm{~mm}$ in the Sahelian zone (Barry, 2007). In the study area, maize water requirements throughout its cycle will be met annually by 
total rainfall. The satisfaction of the total water requirements of maize by considering the total rainfall amounts does not therefore constitute a risk for maize cultivation in the Sudanian and Sudano-Sahelian zones of Burkina Faso. A recent study by Kambire et al. (2010) in Burkina Faso showed that grain yield was not affected by rainfall during the first two months of the maize development cycle. Rather, the rainfall of the third month after sowing and the application of nitrogen fertilization explain the variability of yields. Analysis of the length of the season showed that $80 \%$ of the years it is $\geq 90$ to 100 days approximately in Sudano-Sahelian zone. This length can reach 140 days or more in the Sudanian zone. The length of the rainy season is sufficient in more than $80 \%$ of the years so that maize crops of 100 days in the Sudanian zone and 90 days in the Sudano-Sahelian zone normally close their cycle. The results of the campaign start dates show that the rainy season is mostly settled before the 30th of May in the Sudanian zone and before the beginning of June in the Sudano-Sahelian zone. The relatively high values of the standard deviations of the start dates from the end dates indicate a greater interannual variability of the wintering facility.

It has been noted that in recent years the beginnings and ends of rainy seasons have become less and less predictable for farmers (Sivakumar, 1988, Diop, 1996, Diouf et al., 2000). Analysis of dry sequences at the beginning of the cycle shows that maize can be sown from May in the Sudanian zone and from the first dekad of June in the Sudano-Sahelian zone. However, cross-analysis of probabilities of occurrence of dry sequences $\geq 10$ days, 30 days after sowing and during corn bloom allowed us to locate the favorable seeding period for maize from the third dekad of May for the area Sudanian and the first dekad of June for the Sudano-Sahelian zone. These results confirm the dates of recommendations on the sowing dates of maize in Burkina Faso (Sanou, 1989). Knowledge of the date favorable to sowing makes it possible to reduce the risks of resorestation or occurrence of water stress that is harmful to the vegetative phase. Indeed, the work of Pindard (2000) showed that even if maize can tolerate a water stress during periods of upstream migration and until the first silks are released, dry episodes constitute a constraint for the installation and the good Development of maize.

In Togo, Poss et al. (1998) have Demonstrated that if water requirements at the Flowering corn are satisfied unless $60 \%$, yields become very low, Irrespective of the water conditions on The rest of the cycle.

\section{Materials and Methods}

\subsection{Description of the Study Area}

D'après la classification de Koppen, le climat de la plaine de la Ruzizi appartient au type (AW4) c'est-à-dire à un climat de 4 mois (juin à septembre) au cours des quels les précipitations n'atteignent pas $500 \mathrm{~mm}$ (Germain ,1952), la température varie entre $18^{\circ} \mathrm{C}$ minimum et $29^{\circ} \mathrm{C}$ maximum. La saison des pluies s'étend d'octobre à mai et la saison sèche de juin à septembre.

La répartition annuelle des précipitations est irrégulière. En effet, il n'est pas rare que la saison sèche se prolonge jusqu'en novembre et lorsqu'il arrive de pleuvoir, l'agressivité des premières précipitations ainsi que les ruissellements ne permettent pas au sol de profiter l'apport en eau (Mango, 1996).

L'humidité relative moyenne annuelle est d'environ $70 \%$. On rencontre une saison à faible humidité relatif (55-66\%) de juin en octobre et une saison à haute humidité relative (supérieure à $70 \%$ ) d'octobre en mai. Le régime de l'humidité relative est asynchrone avec le cycle de la précipitation, ce qui veut dire que ce n'est pas le mois le plus sec ou le plus pluvieux qui présente le plus faible ou le plus fort pourcentage d'humidité relative mais le mois qui suit.

L'insolation moyenne annuelle dans la plaine de la Ruzizi est. de l'ordre de $50 \%$ de l'insolation astronomiquement possible. Ainsi, la période d'insolation maximale (supérieure à 50\%) coïncide avec la saison sèche. Elle est suivie par une période d'insolation minimale (41\%) en novembre et décembre (Mashika, 1994). 


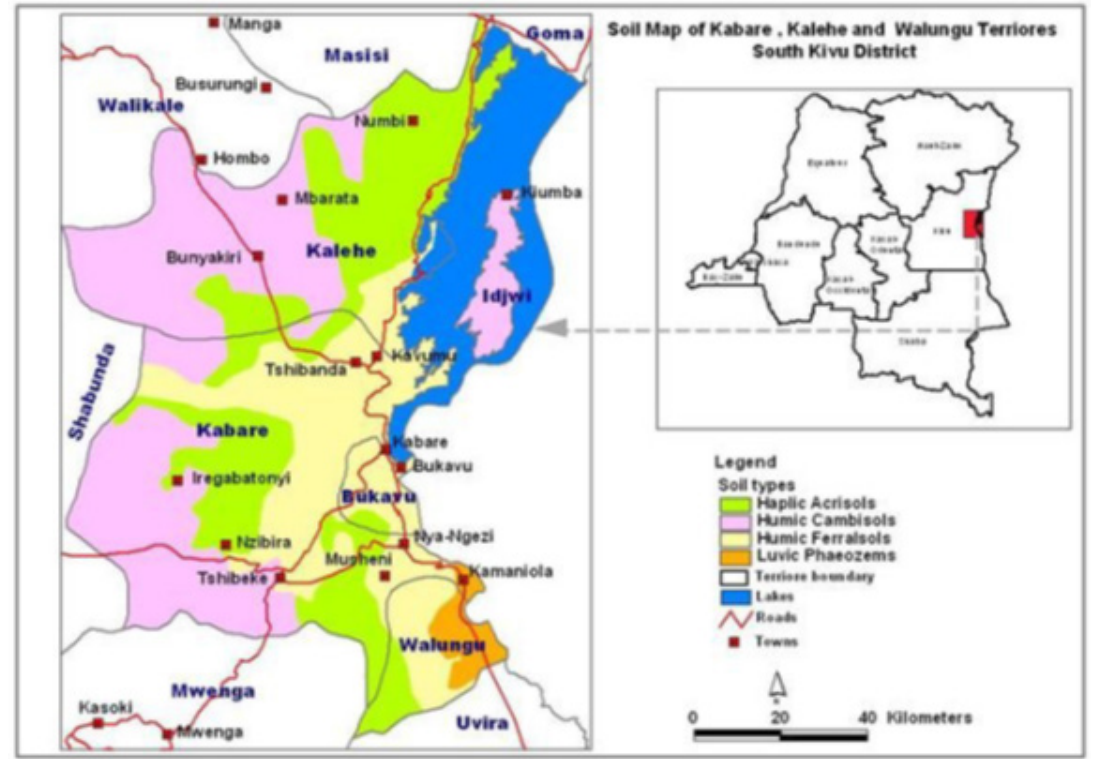

Source: INEAC/ dorsale du kivu

Figure 2. Shows the soils map of South Kivu

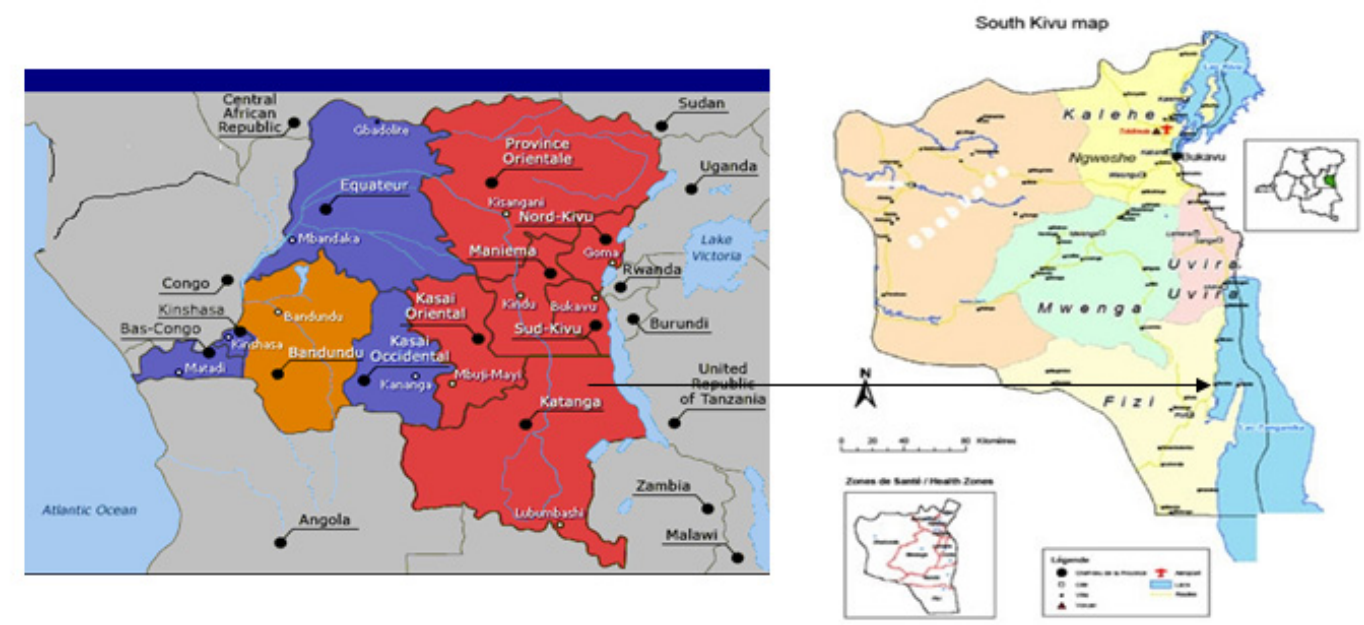

Figure 3. Map of DR Congo

\subsection{Collect Data}

Several levels of information were considered for structuring data and the construction of a simulation unit. The impact assessment of climate change on agriculture required the collection of detailed data on climate and on agricultural production.

\subsection{Data Sources and Quality Assessment}

The monthly meteorological data were obtained from Mparambo station and CRH Uvira for a period $\mathrm{p}$ of 30 years (1995-2015). These include monthly rainfall, minimum and maximum temperatures and transpiration. Data will be captured into Microsoft Excel 2007. The monthly time series from the station were plotted to identify obvious outliers, which will excluded from the data series.

Outliers will be detected using the weatherMan in DSSAT. In fact, WeatherMan is the program for importing, analyzing, and exporting climate data. In addition, the program has a built-in function that can read weather data with different system of measurement (Arnold, 2010).

\subsection{Quality Control and Homogeneity Test}

The data used in this study will carefully analyze in order to identify missing values and eliminate outlying observations. The homogeneity of the data series of Mparambo weather station will be checked by using $\mathrm{R}$ analytical tool (Xuebin and Feng, 2004).

In fact, the lack of homogeneity may be due to records of station moves, changes in instrumentation, problems with instrumentation, sensor calibration and maintenance logs, 
changes in surrounding environmental characteristics and structures, observing practices, and other similar features (Nathaniel, 1998).

\subsection{Trend Analysis}

The mathematical equations for each month over a period of 30 next years for data from local stations were generated in the Eviews software. To find an equation corresponding to a valid series the data was calibrated by a DICKEY-FULLER UNIT ROOT test, so the ADF statistical test should be greater than the standard value of the critical value which is $5 \%$. The maximum proportion beyond which the forecast should be false, called "Bias Proportion" is 0.000000 , or if the prediction tends to be false, it is $\mathrm{Y}(\mathrm{t}-1)=\mathrm{AR} 1$. Y ( $\mathrm{t}-$ Above this value it should be considered as false, the square mean is observed for each month called Root Mean square, then the equations were reproduced in the Excel workbook to generate a time series to observe the trends.

Table showing the series of equations used for the time series, hence t-1 means taking into account the sampling in the last month of the previous year to predict.

Table 1. Represents the mathematical equations for the maximum temperature

\begin{tabular}{ll}
\hline MOIS & EQUATIONS \\
janvier & $\mathrm{Y}(\mathrm{t}-1)=-0,058792 * \mathrm{Yt}+30,62429$ \\
fevrier & $\mathrm{Y}(\mathrm{t}-1)=-0,177633^{\mathrm{Y}} \mathrm{t}+30,89191$ \\
mars & $\mathrm{Y}(\mathrm{t}-1)=-0,210226 * \mathrm{t}+30,82833$ \\
avril & $\mathrm{Y}(\mathrm{t}-1)=0,045523 * \mathrm{Yt}+30,48877$ \\
mai & $\mathrm{Y}(\mathrm{t}-1)=0,184806 * \mathrm{Yt}+30,49450$ \\
juin & $\mathrm{Y}(\mathrm{t}-1)=-0,120882 * \mathrm{Yt}+30,94216$ \\
juillet & $\mathrm{Y}(\mathrm{t}-1)=-0,207184 * \mathrm{Yt}+31,24777$ \\
août & $\mathrm{Y}(\mathrm{t}-1)=0,157041 * \mathrm{Yt}+32,37005$ \\
septembre & $\mathrm{Y}(\mathrm{t}-1)=0,117312 * \mathrm{Yt}+33,05158$ \\
octobre & $\mathrm{Y}(\mathrm{t}-1)=-0,230340 * \mathrm{Yt}+32,44837$ \\
novembre & $\mathrm{Y}(\mathrm{t}-1)=-0,07023 * \mathrm{Yt}+31,16024$ \\
décembre & $\mathrm{Y}(\mathrm{t}-1)=-0,262055 * \mathrm{Yt}+30,63597$
\end{tabular}

carré moyen racinaire proprtion biaisé

0,694774

$0,97933950,000000$

$0,6235350,000000$

$0,7075660,000000$

$0,6420310,000000$

$0,7730830,000000$

$0,7006290,000000$

$0,5993470,000000$

$0,8847370,000000$

$1,0848280,000000$

$0,8174440,000000$

$0,8031690,000000$

Table 1 illustrates the equations of the time series used for the maximum temperature from local stations

Table 2. Represents mathematical equations for the prediction of precipitation

\begin{tabular}{|c|c|c|c|}
\hline & PRECIPITATIONS & & \\
\hline MOIS & Equations & carré moyen racinaire & proportion biaiser \\
\hline janvier & $Y(t-1)=0,224797 * Y t+108,4772$ & & $40.320060,000000$ \\
\hline fevrier & $Y(t-1)=-0,066284 * Y t+94,11365$ & & $30,05604 \quad 0,000000$ \\
\hline mars & $Y(t-1)=0,013715 * Y t+130,7687$ & & $43,47190,000000$ \\
\hline avril & $Y(t-1)=-0,060212 * Y t+131,7180$ & & $47,75268 \quad 0,000000$ \\
\hline mai & $Y(t-1)=-0,202451 * \gamma t+92,13295$ & & $53,341680,000000$ \\
\hline juin & $Y(t-1)=-0,416687 * Y t+18,77353$ & & $16,890120,000000$ \\
\hline juillet & $Y(t-1)=0,089607 * Y t+6,736667$ & & $13,926090,000000$ \\
\hline août & $Y(t-1)=0,004891 * Y t+18,81907$ & & $22,27650,000000$ \\
\hline septembre & $Y(t-1)=-0,000176 * Y t+45,75321$ & & $25,1750,000000$ \\
\hline octobre & $Y(t-1)=0,027318 * Y t+86,37850$ & & $39,858190,000000$ \\
\hline novembre & $Y(t-1)=0,130611 * Y t+98,18367$ & & $39,527930,000000$ \\
\hline décembre & $Y(t-1)=-0,222218 * Y t+89,89614$ & & $37,18065 \quad 0,000000$ \\
\hline
\end{tabular}

Table 2: Represents mathematical equations for the prediction of precipitation

Table 2 illustrates the mathematical equations for the time series of precipitation from local stations. 
Table 3. Represents the mathematical equations for the prediction of the minimum temperature

\begin{tabular}{|c|c|c|}
\hline & TEMPERATURE MINIMAL & \\
\hline MOIS & EQUATIONS & carré moyen racinaire \\
\hline janvier & $Y(t-1)=0,079144 * Y t+17,45406$ & $0,9365960,000000$ \\
\hline fevrier & $Y(t-1)=0,161483 * Y t+17,48373$ & $0,9272780,000000$ \\
\hline mars & $Y(t-1)=0,051269 * Y t+17,65646$ & $0,7331050,000000$ \\
\hline avril & $Y(t-1)=0,370812 * Y t+18,06097$ & $0,8026540,000000$ \\
\hline mai & $Y(t-1)=0,558915 * Y t+17,87701$ & $0,6739930,000000$ \\
\hline juin & $Y(t-1)=0,045211 * Y t+16,08191$ & $0,7351210,000000$ \\
\hline juillet & $Y(t-1)=0,300466 * Y t+14,43829$ & $0,774310,000000$ \\
\hline août & $Y(t-1)=0,216106 * Y t+15,00200$ & $0,8899450,000000$ \\
\hline septembre & $Y(t-1)=-0,062222 * Y t+0,871074$ & $0,8710740,000000$ \\
\hline octobre & $Y(t-1)=-0,106339 * Y t+17,53122$ & $1,4653060,000000$ \\
\hline novembre & $Y(t-1)=-0,072668 * Y t+17,56443$ & $0,795310,000000$ \\
\hline décembre & $Y(t-1)=0,284522 * Y t+17,57276$ & $0,680440,000000$ \\
\hline
\end{tabular}

Table 3: Represents the mathematical equations for the prediction of the minimum temperature

Table 3 illustrates the equations for the minimum local station temperature

\section{Development of the Agricultural Calendar}

To better establish an agricultural calendar and determine the water requirements for corn we used the CROPWAT 8.0 software. The agricultural calendar had been generated by the data here models with a forecast close to the data of the local stations. The results were obtained using the climatic data (maximum and minimum temperature, precipitation) obtained from the site http://www.gismap.ciat.cgiar.org/MarkSimGCM; Maize crop data provided by FAO and soil data, with the plain mostly sandy loam soil.

For this purpose, we have determined the water requirements and the irrigation schedule for the years 2015 and 2045. We used the scenario A1B considered intermediate and whose data are closest to those provided by the data of the local stations taking as a starting point the station of LUBARIKA from CLIMWAT.

\subsection{CROPWAT of Model Inputs}

The Cropwater model was created by the FAO Land and Water Development Division (Italy), with support from the Institute of Irrigation and Development Studies in Southampton (United Kingdom) and the National Water Research Center (Egypt). It has been described by Doorenbos and Pruitt (1977), Smith et al. (1992), and Allen et al. (1998). The model's input and output data can be classified in four categories: (1) climatic data (monthly rainfall, mean monthly maximum and minimum air temperatures, relative humidity, hours of sunshine, wind speed at $2 \mathrm{~m}$, potential evapotranspiration estimated according to the Penman-Monteith equation); (2) agricultural crop data (crop type, sowing period, standard crop coefficient, plant development stages, root depth, plant withering point, plant response capability, crop yields, plant height); (3) soil data (soil type, maximum rain infiltration rate, maximum root depth, initial soil humidity conditions); and (4) irrigation data (e.g., the criteria for implementing irrigation programs).

The Cropwater model can calculate evapotranspiration for crops in two ways: by using the evapotranspiration of reference calculated by the Penman-Monteith equation, or by using the evapotranspiration obtained by direct measurement. In the present study, the evapotranspiration of reference (ETo), was calculated by the Penman-Monteith method, where input consists of maximum and minimum air temperatures, air humidity, sunshine duration and wind speed. Evapotranspiration of crops (ETc) during the growing season is determined as the product of evapotranspiration of reference (ETo) and crop coefficient (Kc) (Equation 1; Allen et al., 1998):[15] ETc $=$ ETo $*$ Kc (Eq. 1) Crop coefficient values for each time lapse are estimated by linear interpolation of $\mathrm{Kc}$ values for each stage of crop development.

The Cropwat is an aid to the management of irrigation, it was developed by the FAO in 1992, based on the modified Penman - Monteith formula. Using the original Penman-Monteith equation and the aerodynamic and surface resistance equations, the FAO Penman-Monteith method for estimating ETo can be expressed as:

$(++)$

Or:

Eto: reference evapotranspiration [mm day-1],

$\mathrm{Rn}$ : net radiation at the surface of the culture $[\mathrm{MJ} \mathrm{m}-2$ day-1],

$\mathrm{G}$ : density of heat flux in the soil [MJ m-2 day-1],

$\mathrm{T}$ : mean daily air temperature at a height of $2 \mathrm{~m}\left[{ }^{\circ} \mathrm{C}\right]$

$\mathrm{U} 2$ : wind speed at a height of $2 \mathrm{~m} \mathrm{[m} \mathrm{s-1]}$,

Es: saturating vapor pressure $[\mathrm{kPa}]$,

Ea: actual vapor pressure $[\mathrm{kPa}]$, 
Es-ea: saturating vapor pressure deficit $[\mathrm{kPa}]$,

D: slope of saturation vapor pressure curve $\left[\mathrm{kPa}^{\circ} \mathrm{C}-1\right]$,

G: psychrometric constant $\left[\mathrm{kPa}^{\circ} \mathrm{C}-1\right]$.

It allows the calculation of the water needs of crops and the quantities of irrigation water; Based on FAO-24 and 33 Irrigation and Drainage Bulletins. It also offers the opportunity to develop an irrigation schedule for various cropping practices, and to assess the effects of water shortage on crops and the efficiency of different irrigation practices (Boudjelal, 2007) .CROPWAT 8.0 is a computer program for calculating crop water requirements and irrigation needs based on soil data, climate and crop. In addition, the program allows the development of irrigation schemes for different management conditions and calculation of clean water supply for different crop types

\section{Entering Culture Data}

For these data, we used those available in the cropwat database by choosing those that correspond to the crop studied. The sowing dates used are those of the study environment for the crop according to the corresponding model.

Table 4. Represents maize crop data

\begin{tabular}{|c|c|c|c|c|c|}
\hline \multirow{2}{*}{\multicolumn{6}{|c|}{$\begin{array}{l}\text { DONNEE GENERAL SUR LA CULTURE } \\
\text { DONNEE GENERAL SUR LA CULTURE }\end{array}$}} \\
\hline & & & & & \\
\hline LACULTURE & MAïS & & & & \\
\hline DATE DE PLANTATION & le 2819 & & & & \\
\hline PHASE JOURS & Initiale:20 & Croissance :35 & mis-saison:40 & Arriere-saison:30 & totale: 125 \\
\hline KS VALEURS & 0.3 & 1.20 & 0.35 & & \\
\hline Profondeur racinaire & 0,3 & & 1.00 & & \\
\hline Epouisement maximum & 0,55 & & 0,55 & 0,8 & \\
\hline Reponse de rendement & 0,4 & 0,4 & 1,3 & 0,5 & 1,25 \\
\hline Hauteur de la culture & & & 2.00 & & \\
\hline
\end{tabular}

Soil Related Data

Table 5. Reproduces soil data from the study environment

\begin{tabular}{lr}
\hline DONNEES GENERAL SUR LE SOL & VALEUR \\
Nom du sol:RED SANDY LOAM & \\
Eau disponible total(CC(PF) & $140 \mathrm{~mm} / \mathrm{metre}$ \\
Taux d'infiltration maximum de l'eau de pluies & $30 \mathrm{~mm} / \mathrm{jours}$ \\
profondeur maximum d'enrecinement & 900 centimetres \\
epuisement de la teneur en eau inititiale(en\%) & $0 \%$ \\
Eau disponible initiale & $140 \mathrm{~mm} / \mathrm{metre}$ \\
\hline
\end{tabular}

- Soil data are not included in the calculation of water requirements, but are necessary in the cropwat software for the rest of the work. For this purpose, the cropwat soil database is used by selecting the soils corresponding to the soils of the study environment.

- The entry data for the model are precipitation, maximum temperature and minimum temperature of the ECHAM-5 model.

Statistical Tests Used

The data obtained was encoded in Excel workbook. Analysis of variance for the comparison of averages between scenarios and years for different data obtained; Statistica software. The chosen significance level was 5

\section{Results and Discussion}

Maps of changes in the DRC according to the Echam-5 model for the period 2015-2045 


\section{Change in Precipitation}
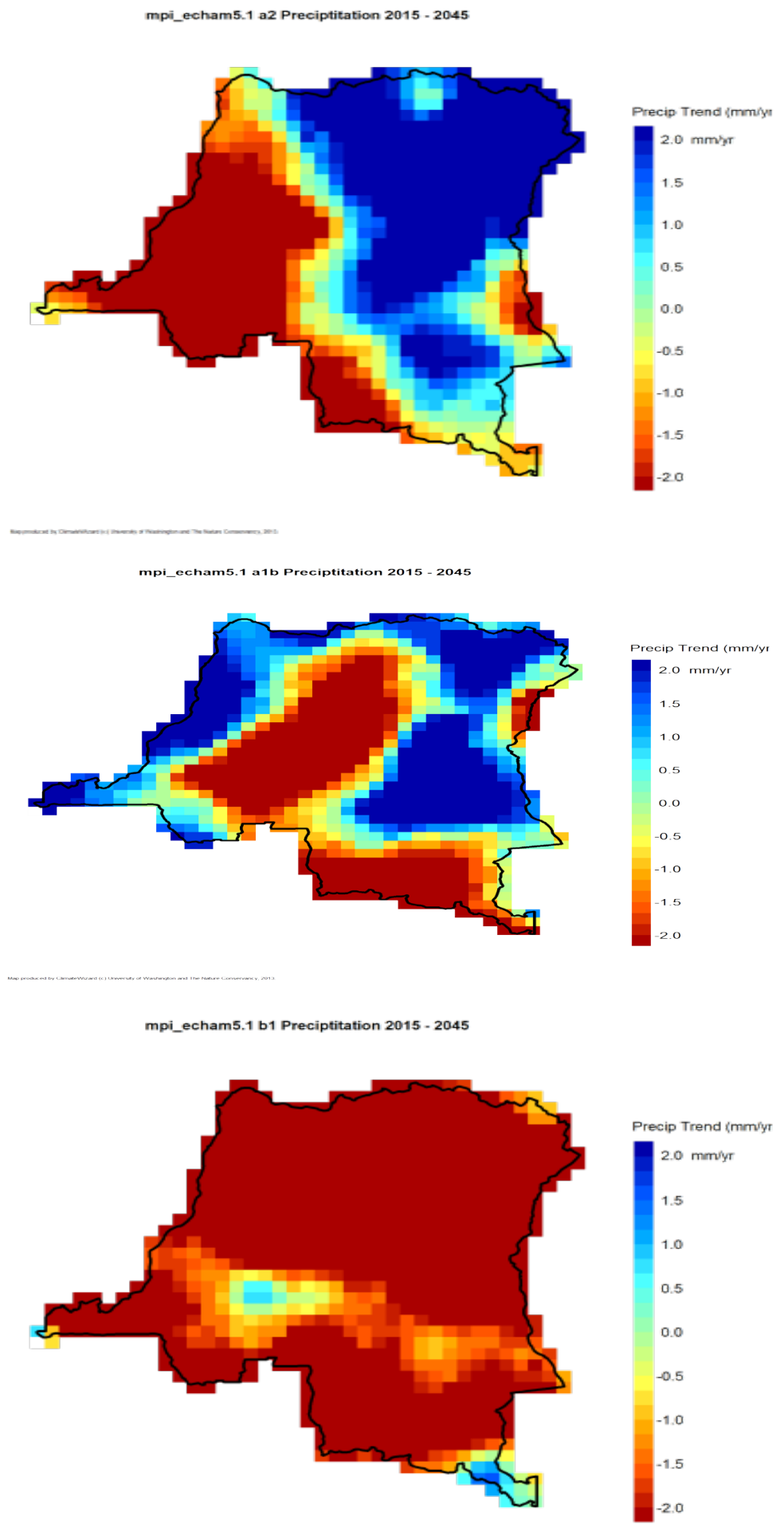

Figure 4. The change in scenario 1, AIB at B1 precipitation from 2015 to 2045

From this figure, scenario A2 has a tendency to increase by $2 \mathrm{~mm}$ of rain per year in the northeastern part of the country. The reverse trend is observed in the southwestern part, where a decrease of $2 \mathrm{~mm}$ in annual rainfall is observed. In other parts of the country the variation is in a varied range. Scenario A1B, on the other hand, has some variability in the distribution of changes. An increase in precipitation is observed in the eastern part and more to the west of the country. On the other hand, there is a decrease in the center and in the southeast. Scenario B1, in turn, has 
a decrease in precipitation of about $2 \mathrm{~mm} /$ year throughout the country. In the central and southern parts there is a slight increase in precipitation. It can therefore be concluded that in some parts of the country there will be an increase in the amount of precipitation and in others a decrease in rainfall.
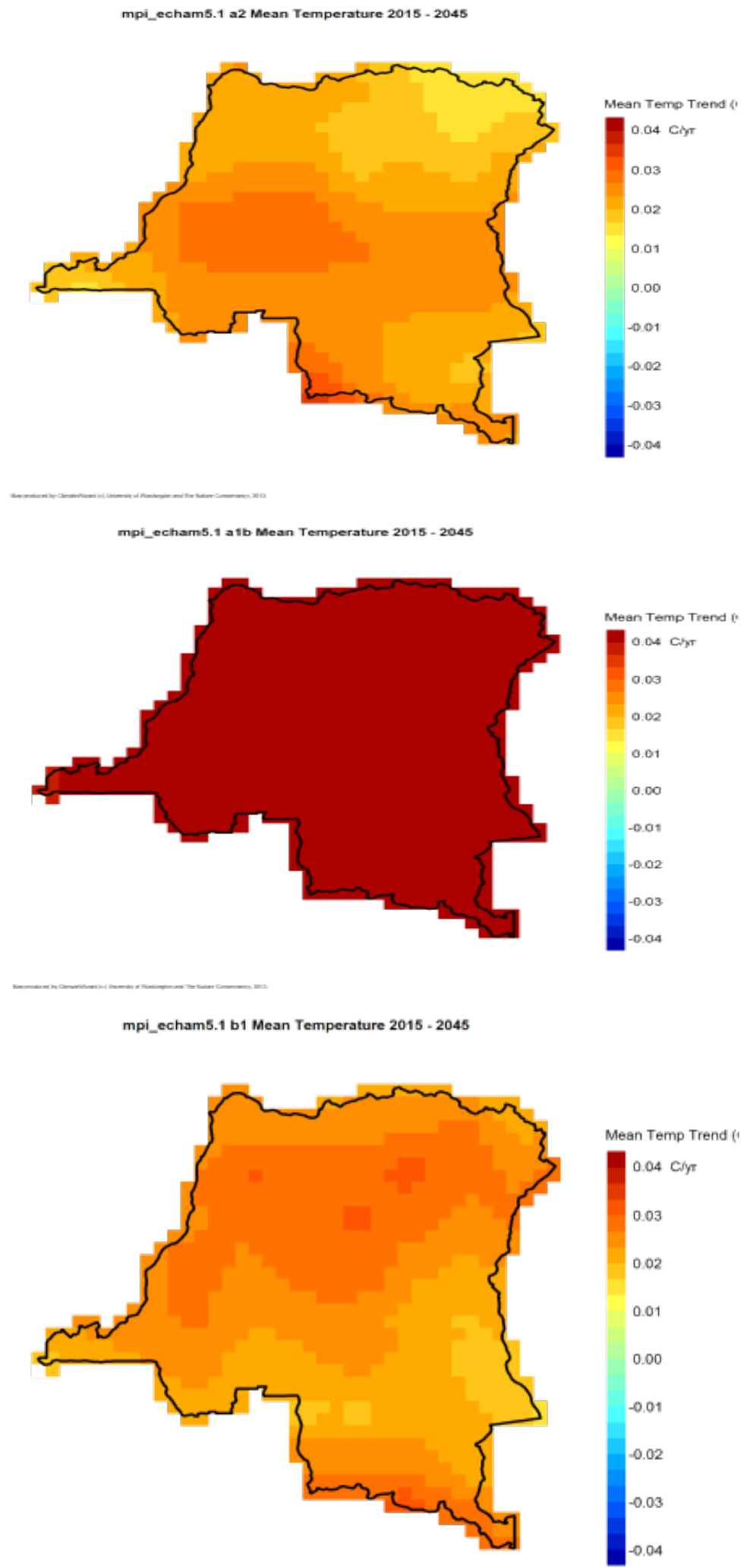

Figure 5. The variation of scenario temperatures A1, AIB at B1 from 2015 to 2045 
From the 3 figures above, it can be seen that the first scenario shows an increase varying between $0.03{ }^{\circ} \mathrm{C}-0.04^{\circ}$ $\mathrm{C}$ per year for the whole country. The trend in scenario A1B shows an increase of more than $0.04{ }^{\circ} \mathrm{C}$ for the whole country. Scenario B1 in turn shows the same trend as scenario B1.

It can therefore be said that overall there will be an increase in temperatures throughout the Congolese territory.

\section{Data Provided by the Local Station (from 1965 to 1995)}

Figure 6 shows the results of the quantity and the distribution of rainfall in the RUZIZI plain for the period 1965 to 1995 . Observing the graph we note that over time there is great variability in the distribution of precipitation. There is also an increase in the amount of precipitation. For the different years the months of July and August were marked by a pronounced dryness of less than $7 \mathrm{~mm}$ for all years. For the year 1965 we notice a more or less balanced distribution of precipitation for the different months. The year 1975 was marked by a significant amount of precipitation in March (225.5mm). For 1985 and 1995, this situation was observed successively for April $(275.5 \mathrm{~mm})$ and December $(277.7 \mathrm{~mm})$. We note in all a very great variability in the distribution of precipitation.

From the above it may be said that in the whole of the reality of the plain there is an increase in the quantity of precipitation with a modification in its distribution. It follows that the data provided by the models do not deviate much from the reality of the local environment.

For the ensemble, the presence of precipitation has varied greatly during the last 11 years, this graph shows the presence of precipitation in January to May for most of the years and the dry period to summer Known in the months of June to the month of September, when the resumption of precipitation was observed from October to December. The considerable amount of precipitation was known in January to the month of April While other months experienced a fall in rainfall.

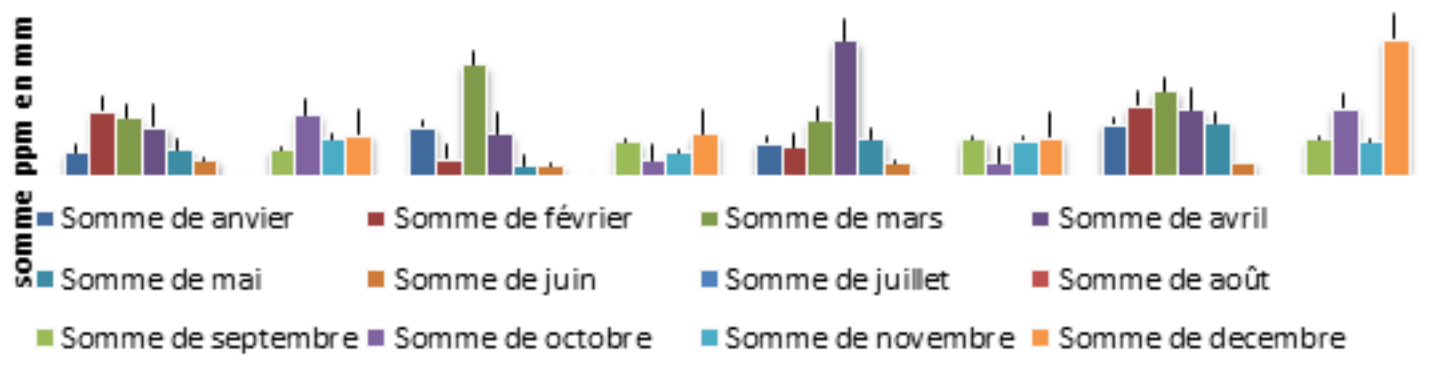

Figure 6. The local precipitation data for the Mparambo station from 1965 to 1995

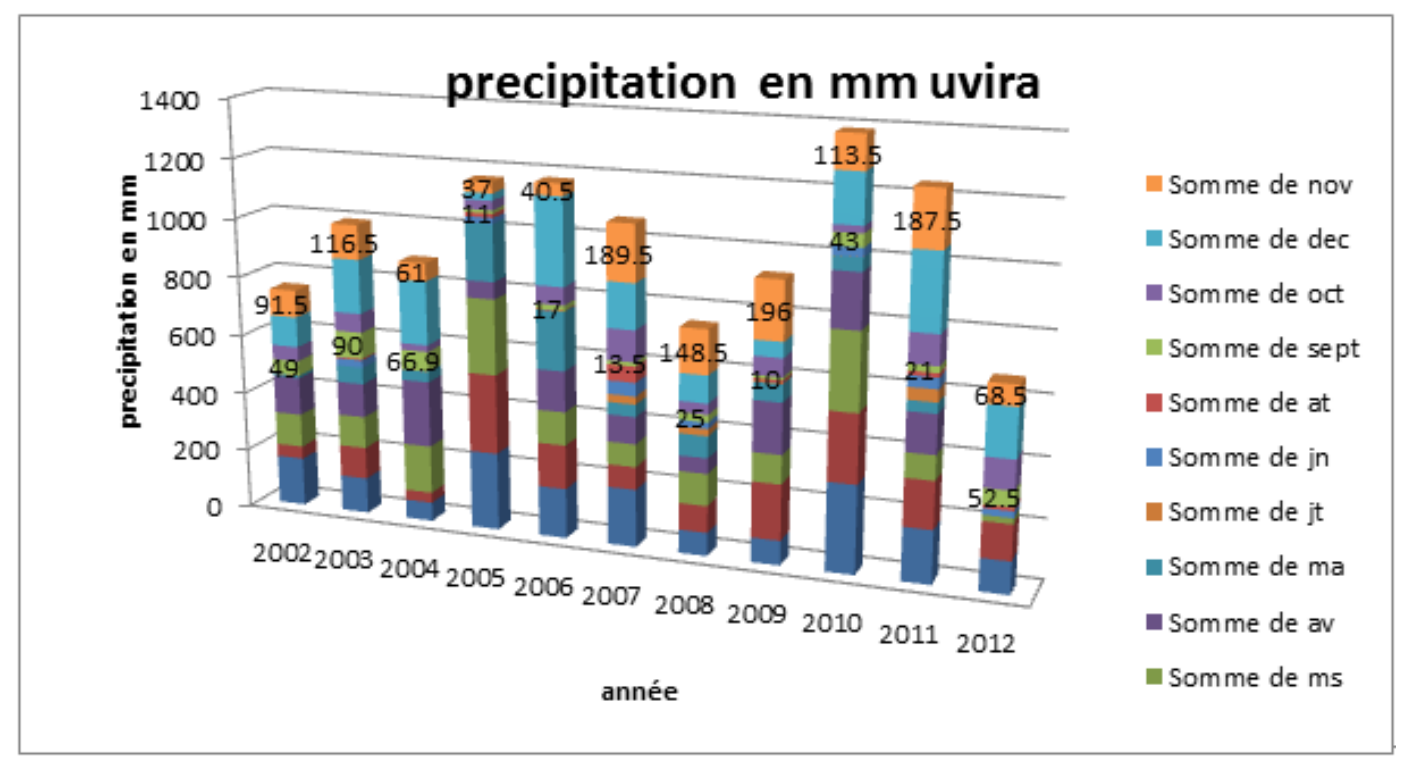

Figure7. The evolution and the distribution of precipitations, CRH-UVIRA station (2002-2012) 
Predictions of local stations show a change in rainfall, indicating that precipitation occurs between September and May between $132 \mathrm{~mm}$ and $76 \mathrm{~mm}$ of rainfall, after which four seasons should be observed as the dry season, August.

Compared to the model forecasts, the rainy season will show a sum of precipitation distributed over a 9-month period, from September to May and between. In June, July and October will be observed a dry period of the year and this for all the years as well as the scenarios. Nevertheless there is a tendency in falls suddenly during the month of October in the distributions those that can hinder the cycles of the culture because maize is a crop that is very sensitive to the drought (Sarr et al. , 1999) There is a fall in the precipitation heights for the years 2015 and 2045 compared to the other years. The climate model approaching local station forecasts is the echam- 5 model in Scenario B1.

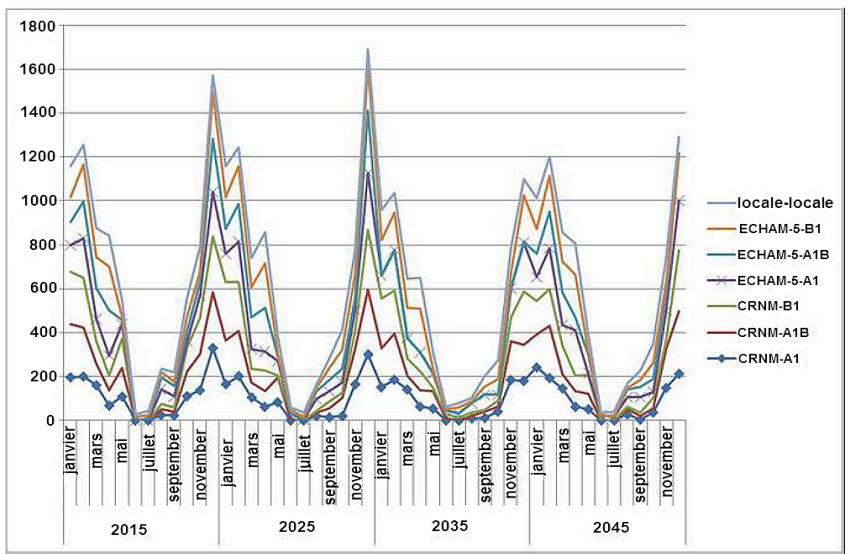

Figure 8. Forecasting of precipitation between climate models and local stations

Table 6. Maximum means temperatures for local station data Climate models

\begin{tabular}{|c|c|c|c|c|c|c|c|c|c|c|c|}
\hline \multicolumn{2}{|c|}{ Moyenne de TEMP MAX } & \multicolumn{10}{|c|}{ Modeles scenarios } \\
\hline & \multicolumn{3}{|l|}{ Average } & \multicolumn{6}{|l|}{ CRNM } & \multirow{2}{*}{\begin{tabular}{|l} 
locale \\
locale \\
\end{tabular}} \\
\hline INEE & MOIS & $A 1$ & B1 & $A 1 B$ & A1 & B1 & $A 1 B$ & A1 & B1 & $A 1 B$ & \\
\hline \multirow[t]{12}{*}{201} & 5 ]janvier & & 29,6241935 & 29,9387097 & 30,383871 & 29,9580645 & 29,9580645 & 29,9964286 & 29,9142857 & 29,925 & 29,5099365 \\
\hline & fevrier & 30,5785714 & t 30,3785714 & 30,5285714 & 31,0392857 & 30,925 & 29,9580645 & 31,783871 & 31,0516129 & 31,0387097 & 27,1881241 \\
\hline & mars & 30,9935484 & 31,2225806 & 31,0451613 & 31,4967742 & 31,5935484 & 30,925 & 30,3466667 & 29,94 & 29,7466667 & 26,9158965 \\
\hline & avril & 30,2866667 & 29,96 & 29,6933333 & 30,7333333 & 30,3633333 & 31,5935484 & $+30,7290323$ & 31,1483871 & 30,8129032 & 31,795517 \\
\hline & mai & 30,983871 & 131,0129032 & 30,9935484 & 31,0096774 & 30,5451613 & 30,3633333 & 328,1766667 & 27,9033333 & 28,0133333 & 33,451396 \\
\hline & juin & 28,02 & 27,72 & 27,7833333 & 28,2666667 & 27,9066667 & 27,9066667 & 32,2580645 & 31,5322581 & 31,7290323 & 28,4471714 \\
\hline & juillet & 31,6548387 & 31,8935484 & 31,4483871 & 32,0354839 & 31,8419355 & 31,8419355 & 30,2709677 & 29,8032258 & 29,9451613 & \begin{tabular}{l|l}
3 & 27,2827258
\end{tabular} \\
\hline & août & 30,0677419 & 30,2032258 & 29,9290323 & 30,7 & 31,0129032 & 31,0129032 & 2 31,4633333 & 30,8866667 & 30,4733333 & 35,1909229 \\
\hline & septembre & 31,51 & 31,27 & 31,4266667 & 32,3233333 & 32,6566667 & 32,6566667 & 30,3451613 & 30,483871 & 30,5645161 & 134,9105242 \\
\hline & octobre & 31,1096774 & + 30,916129 & 31,1032258 & 31,7451613 & 31,4129032 & 31,4129032 & 30,99 & 30,85 & 30,6666667 & 28,6766617 \\
\hline & novembre & 31,1633333 & $3 \quad 30,9733333$ & 31,2433333 & 31,7451613 & 32,05 & 32,05 & 32,3 & 31,5612903 & 31,8193548 & 32,8851597 \\
\hline & décembre & 31,7967742 & 32,2064516 & 31,6709677 & 32,3612903 & 32,2096774 & 32,2096774 & 29,0870968 & 29,3322581 & 29,0612903 & 26,2222655 \\
\hline \multicolumn{2}{|l|}{ Total 2015} & 30,7422748 & 30,5388562 & 30,5670225 & 31,1533365 & 31,039655 & 30,9907303 & 30,6456074 & 30,3672657 & 30,3163306 & $6 \quad 30,2063584$ \\
\hline \multirow[t]{12}{*}{2045} & 5 janvier & 30,8225806 & 30,6419355 & 30,2870968 & 31,016129 & 30,4032258 & 30,6 & 30,016129 & 29,9483871 & 29,9258065 & 28,9238018 \\
\hline & fevrier & 31,5428571 & 1 31,5928571 & 31,3428571 & 31,8821429 & 31,9428571 & 31,4535714 & + 31,5642857 & 31,4464286 & 31,1642857 & 26,2322048 \\
\hline & mars & 31,9516129 & 31,6483871 & 31,5483871 & 32,616129 & 31,316129 & 31,9483871 & 32,4129032 & 32,3 & 31,8935484 & 25,4732009 \\
\hline & avril & 30,8333333 & $3 \quad 30,9733333$ & 31,03 & 31,3233333 & 31,6333333 & 30,9166667 & 31,4433333 & 31,3366667 & 30,89 & 31,942907 \\
\hline & mai & 32,2354839 & 31,5451613 & 31,4548387 & 32,4258065 & 31,2677419 & 31,5419355 & 32,5677419 & 31,9064516 & 32,0580645 & 37,40766 \\
\hline & juin & 29,0866667 & 28,7433333 & 28,6166667 & 28,94 & 29,68 & 28,4666667 & 29,3933333 & 29,5366667 & 29,1857143 & 27,6051895 \\
\hline & juillet & 32,4516129 & 32,4516129 & 32,3193548 & 32,8225806 & 31,516129 & 32,1709677 & 33,083871 & 33,2645161 & 32,8354839 & 9) 25,8848444 \\
\hline & août & 31,116129 & 31,0612903 & 30,9483871 & 31,516129 & 32,1806452 & 31,2709677 & 31,7741935 & 31,3387097 & 31,316129 & 38,4005035 \\
\hline & septeml & 32,3666667 & 32,2833333 & 32,1633333 & 33,19 & 33,1466667 & 32,6 & 32,9666667 & 32,2366667 & 32,23 & 37,4442385 \\
\hline & octobre & 32,1290323 & 331,7258065 & 31,5483871 & 32,8225806 & 32,0709677 & 32,0806452 & 31,9967742 & 32 & 31,4612903 & 26,3734984 \\
\hline & novembre & 32,1433333 & $3 \quad 31,9666667$ & 31,5866667 & 32,5366667 & 33,4633333 & 32,0266667 & 32,4566667 & 32,7870968 & 31,55 & 33,5139336 \\
\hline & décembre & 32,7096774 & $+32,8419355$ & 32,5790323 & 33,0612903 & 32,6 & 32,6548387 & 32,616129 & & & 24,2746711 \\
\hline \multicolumn{2}{|l|}{ otal 2045} & 31,6157488 & 31,4563044 & 31,3849261 & 32,0127323 & 31,7684191 & 31,4776094 & 31,857669 & 31,6455991 & 31,3191202 & 30,2897211 \\
\hline
\end{tabular}


An increase of one degree for all the scenarios of the average model will be observed between the year 2015 and the year ie $30,7^{\circ} \mathrm{C}$ and 31,6 for the scenarios $\mathrm{A} 1,30,5$ and $31,4^{\circ} \mathrm{C}$ for The scenarios $\mathrm{A} 1 \mathrm{~B}$ and $30.5^{\circ} \mathrm{C}$ and $31.3^{\circ} \mathrm{C}$ in scenarios B1. For the scenario group at the level of the CNRM model, scenarios A1 will have to record an average temperature of $31.1^{\circ} \mathrm{C}$ in 2015 and $32^{\circ} \mathrm{C}$ in 2045 , while in scenario $\mathrm{A} 1 \mathrm{~B}$ the maximum mean temperature will range from $30.9^{\circ} \mathrm{C}$ in 2015 to $31.7^{\circ} \mathrm{C}$ in 2045 , while in scenario $\mathrm{B} 1$ the average annual temperature will be $31^{\circ} \mathrm{C}$ And $31.4^{\circ} \mathrm{C}$. At the level of the ECHAM-5 model scenarios A1 should have a maximum moisture temperature of $30.6^{\circ} \mathrm{C}$ for the year 2015 and $31.4^{\circ} \mathrm{C}$ for the year 2045, the scenarios of the A1B group will have an average temperature Annual of 30.3 in 2015 and $31.6^{\circ} \mathrm{C}$ in
2045 in turn scenario B1 will have a maximum average between $30.3^{\circ} \mathrm{C}$ and $31.3^{\circ} \mathrm{C}$.

At the local stations the average annual temperature will have to vary between 30 between the year 2015 and the year 2045.

At the level of the Average model the minimum average temperature will have to increase by one degree between the year 2015 and the year 2045 , ie $18^{\circ} \mathrm{C}$ and $19^{\circ} \mathrm{C}$ for all the scenarios and will have to be maintained at $19^{\circ} \mathrm{C}$ in the CNRM model. At the level of the echam-5 model, the minimum average temperature will have to resume at a rate of $18^{\circ} \mathrm{C}$ for the year 2015 and $19^{\circ} \mathrm{C}$ for the year 2045 . At the local station level, a minimum average temperature of $19,5^{\circ} \mathrm{C}$.

Table 7. Prediction of minimum mean temperature between climate models and local stations

\begin{tabular}{|c|c|c|c|c|c|c|c|c|c|c|c|}
\hline \multirow{2}{*}{\multicolumn{2}{|c|}{ Moyenne de TEMP MIN }} & \multicolumn{10}{|c|}{ Modeles scenarios } \\
\hline & & \multicolumn{3}{|l|}{ Average } & \multicolumn{3}{|l|}{ CRNM } & \multicolumn{3}{|l|}{ ECHAM-5 } & \multirow{2}{*}{$\frac{\text { locale }}{\text { locale }}$} \\
\hline ANNEE & MOIS & A1 & $A 1 B$ & B1 & A1 & $A 1 B$ & B1 & A1 & $A 1 B$ & B1 & \\
\hline \multirow[t]{12}{*}{201} & janvier & & 20,0096774 & 19,8887097 & 20,7129032 & 20,5483871 & 20,5483871 & 19,9129032 & 19,7032258 & 19,8645161 & 18,9541687 \\
\hline & fevrier & 18,9928571 & 19,0678571 & 18,675 & 19,8357143 & 19,5392857 & 19,5392857 & 18,425 & 18,6071429 & 18,5714286 & 20,8507758 \\
\hline & mars & 19,4774194 & 19,5387097 & 19,6129032 & 20,3032258 & 20,3548387 & 20,5548387 & 19,8451613 & 19,5322581 & 19,3709677 & $\mid 18,6106072$ \\
\hline & avril & 20,05 & 19,8866667 & 19,9533333 & 20,7166667 & 20,7166667 & 20,7166667 & 20,05 & 19,9633333 & 19,8633333 & 28,7052041 \\
\hline & mai & 20,2096774 & 20,4548387 & 19,9322581 & 20,6709677 & 20,0516129 & 20,0516129 & 19,7258065 & 19,8225806 & 19,8354839 & \\
\hline & juin & 14,9066667 & 14,7566667 & 14,8566667 & 15,3466667 & 15,3733333 & 15,7733333 & 14,8666667 & 14,6666667 & 14,7333333 & 20,6398688 \\
\hline & juillet & 17,8645161 & 17,6709677 & 18,0322581 & 18,7193548 & 18,5483871 & 18,5483871 & 17,9419355 & 17,6483871 & 17,4870968 & 19,1377916 \\
\hline & août & 15,4064516 & 15,5548387 & 15,7193548 & 16,4419355 & 16,7032258 & 16,7032258 & 16,0580645 & 15,4483871 & 15,1967742 & 17,9626522 \\
\hline & septembre & 17,91 & 17,7866667 & 17,49 & 18,6766667 & 18,0733333 & 18,0733333 & 17,17 & 17,1233333 & 17,3633333 & 15,8461557 \\
\hline & octobre & 17,4193548 & 17,5258065 & 17,5548387 & 18,2806452 & 18,3354839 & 18,3354839 & 17,2387097 & 17,0645161 & 17,0677419 & 16,3745259 \\
\hline & novembre & 19,25 & 19,2266667 & 19,4266667 & 20,17 & 20,5166667 & 20,5166667 & 19,49 & 19,1833333 & 19,13 & 24,560867 \\
\hline & décembre & 21,0354839 & 20,8967742 & 21,1451613 & 21,9354839 & 21,6903226 & 21,6903226 & 20,9774194 & 20,9225806 & 20,8741935 & 16,8426647 \\
\hline \multicolumn{2}{|l|}{ Total 2015} & 18,4111297 & 18,5313447 & 18,6289123 & 19,3175192 & 19,2042953 & 19,2042953 & 18,4751389 & 18,3071454 & 18,2798502 & 19,5404402 \\
\hline \multirow[t]{12}{*}{204} & anvier & 20,9193548 & 20,7419355 & 20,4290323 & 21,2451613 & 20,6516129 & 20,8677419 & 21,0258065 & 20,6806452 & 20,4645161 & 18,9541687 \\
\hline & fevrier & 19,95 & 19,8607143 & 19,5892857 & 20,2357143 & 20,2678571 & 19,8428571 & 19,6928571 & 19,6678571 & 19,4321429 & 20,8507758 \\
\hline & mars & 20,4741935 & 20,4419355 & 20,183871 & 20,7225806 & 19,9064516 & 20,1741935 & 20,4870968 & 20,6677419 & 20,5 & 18,6106072 \\
\hline & avril & 21,0933333 & 21,05 & 20,7566667 & 21,0133333 & 21,29 & 20,6033333 & 21,5066667 & 21,0666667 & 20,9033333 & 28,7052042 \\
\hline & mai & 21,2516129 & 21,0709677 & 20,8032258 & 21,316129 & 20,3580645 & 20,616129 & 20,8935484 & 20,916129 & 20,5419355 & \\
\hline & juin & 16,2066667 & 16,1433333 & 15,7566667 & 15,9933333 & 16,2966667 & 15,5333333 & 16,2933333 & 16,0266667 & 15,3928571 & 20,6398688 \\
\hline & juillet & 18,983871 & 19,0967742 & 18,6193548 & 19,083871 & 18,4290323 & 18,5645161 & 19,0290323 & 18,9032258 & 18,5451613 & 19,1377916 \\
\hline & août & 16,8225806 & 16,8193548 & 16,3483871 & 17,2096774 & 18,1870968 & 16,3612903 & 17,683871 & 16,9612903 & 16,5580645 & 17,9626522 \\
\hline & septembre & 19,03 & 18,7166667 & 18,4833333 & 19,1433333 & 18,66 & 18,6633333 & 18,46 & 18,55 & 18,3033333 & 15,8461557 \\
\hline & octobre & 18,5225806 & 18,4193548 & 18,116129 & 18,8548387 & 18,5419355 & 18,3225806 & 18,4 & 18,3290323 & 17,9967742 & 16,3745259 \\
\hline & novembre & 20,2733333 & 20,1433333 & 19,9066667 & 20,4766667 & 21,3 & 20,04 & 20,7733333 & 20,1366667 & 19,76 & 24,560867 \\
\hline & décembre & 21,8870968 & 21,8741935 & 20,3436627 & 22,0935484 & 21,7677419 & 21,6580645 & 21,7225806 & 21,8709677 & & 16,8426647 \\
\hline Total 2045 & & 19,6178853 & 19,531547 & 19,2061496 & 19,4452198 & 19,782349 & 19,6380383 & & 19,6640105 & 19,4814075 & 19,3755181 \\
\hline
\end{tabular}




\section{Agricultural Plan 2015-2045}

Need for Water from Maize Cultivation

Year 2015

The water requirement for the maize crop for 2015

Table 9 shows the variation in non-standard evapotranspiration (ETc1 in $\mathrm{mm} /$ day and ETc2 in $\mathrm{mm}$ per decade), effective rainfall and irrigation needs in relation to the growth phases of the maize crop for the year 2015 .
For the initiation phase the ETc2 is> effective precipitation. This necessitates a need for irrigation. During the growth phase we notice a clear increase in irrigation needs because ETc2 is considerably higher than effective precipitation. The mid-season phase also shows a need for irrigation because we also find that the ETC2 is $>$ to effective precipitation. The out-of-season phase shows a need for nil irrigation because for this there is an opposite effect.

Table 8. Water requirements of maize crops for the year 2015

\begin{tabular}{|c|c|c|c|c|c|c|c|}
\hline Mois & Décade & Phase & $\begin{array}{l}\text { Kc } \\
\text { coeff }\end{array}$ & $\begin{array}{l}\text { ETc } \\
\mathrm{mm} / \text { jour }\end{array}$ & $\begin{array}{l}\text { ETc } \\
\mathrm{mm} / \mathrm{dec}\end{array}$ & $\begin{array}{l}\text { Pluie eff. } \\
\mathrm{mm} / \mathrm{dec}\end{array}$ & $\begin{array}{l}\text { Bes. Irr. } \\
\mathrm{mm} / \mathrm{dec}\end{array}$ \\
\hline Sep & & 3 Init & 0.30 & 1.30 & 3.9 & 4.0 & 3.9 \\
\hline Oct & & 1 Init & 0.30 & 1.28 & 12.8 & 8.3 & 4.5 \\
\hline Oct & & 2 Crois & 0.31 & 1.31 & 13.1 & 4.7 & 8.4 \\
\hline Oct & & 3 Crois & 0.52 & 2.10 & 23.1 & 12.5 & 10.6 \\
\hline Nov & & 1 Crois & 0.77 & 3.05 & 30.5 & 21.8 & 8.7 \\
\hline Nov & & 2 Crois & 1.01 & 3.90 & 39.0 & 28.4 & 10.6 \\
\hline Nov & & $3 \mathrm{Mi}$-sais & 1.14 & 4.44 & 44.4 & 34.0 & 10.4 \\
\hline Déc & & $1 \mathrm{Mi}$-sais & 1.14 & 4.47 & 44.7 & 42.4 & 2.3 \\
\hline Déc & & 2 Mi-sais & 1.14 & 4.49 & 44.9 & 49.5 & 0.0 \\
\hline Déc & & $3 \mathrm{Mi}$-sais & 1.14 & 4.43 & 48.8 & 43.6 & 5.1 \\
\hline Jan & & 1 Arr-sais & 1.00 & 3.82 & 38.2 & 34.0 & 4.1 \\
\hline Jan & & 2 Arr-sais & 0.73 & 2.77 & 27.7 & 28.4 & 0.0 \\
\hline Jan & & 3 Arr-sais & 0.47 & 1.78 & 17.8 & 30.1 & 0.0 \\
\hline
\end{tabular}

Table 9. Water requirements of maize crop for the year 2015

\begin{tabular}{|c|c|c|c|c|}
\hline & Valeurs & & & \\
\hline PHASE & Somme de Bes,Irr, & Somme de Pluie eff, & Somme de ETc2 & Somme de Etc \\
\hline Arr-sais & 4,1 & 92,5 & 83,7 & 8,37 \\
\hline Crois & 38,3 & 67,4 & 105,7 & 10,36 \\
\hline Init & 8,4 & 12,3 & 16,7 & 2,58 \\
\hline Mi-sais & 17,8 & 169,5 & 182,8 & 17,83 \\
\hline Total général & 68,6 & 341,7 & 388,9 & 39,14 \\
\hline
\end{tabular}

Table 10. The water requirement for the maize crop for the year 2045

\begin{tabular}{|c|c|c|c|c|c|c|c|}
\hline Mois & Décade & Phase & $\begin{array}{l}\text { Kc } \\
\text { coeff }\end{array}$ & $\begin{array}{l}\text { ETc } \\
\mathrm{mm} / \text { jour }\end{array}$ & $\begin{array}{l}\text { ETc } \\
\mathrm{mm} / \mathrm{dec}\end{array}$ & $\begin{array}{l}\text { Pluie eff. } \\
\text { mm/dec }\end{array}$ & $\begin{array}{l}\text { Bes. Irr. } \\
\mathrm{mm} / \mathrm{dec}\end{array}$ \\
\hline Sep & & 3 Init & 0.30 & 1.34 & 4.0 & 5.5 & 4.0 \\
\hline Oct & & 1 Init & 0.30 & 1.32 & 13.2 & 8.7 & 4.4 \\
\hline Oct & & 2 Crois & 0.31 & 1.36 & 13.6 & 2.8 & 10.8 \\
\hline Oct & & 3 Crois & 0.51 & 2.17 & 23.8 & 13.5 & 10.4 \\
\hline Nov & & 1 Crois & 0.77 & 3.15 & 31.5 & 27.3 & 4.2 \\
\hline Nov & & 2 Crois & 1.00 & 4.03 & 40.3 & 36.8 & 3.5 \\
\hline Nov & & 3 Mi-sais & 1.14 & 4.55 & 45.5 & 40.5 & 4.9 \\
\hline Déc & & 1 Mi-sais & 1.14 & 4.54 & 45.4 & 46.5 & 0.0 \\
\hline Déc & & 2 Mi-sais & 1.14 & 4.53 & 45.3 & 52.4 & 0.0 \\
\hline Déc & & 3 Mi-sais & 1.14 & 4.47 & 49.2 & 45.0 & 4.2 \\
\hline Jan & & 1 Arr-sais & 0.99 & 3.86 & 38.6 & 33.4 & 5.2 \\
\hline Jan & & 2 Arr-sais & 0.73 & 2.80 & 28.0 & 26.0 & 2.0 \\
\hline Jan & & 3 Arr-sais & 0.47 & 1.82 & 18.2 & 28.8 & 0.0 \\
\hline
\end{tabular}


Table 11 shows the variation in non-standard evapotranspiration, effective rainfall and irrigation requirements for crop growth phases for the year 2045. For the initiation phase we find that water requirements are low because that the sum of Effective Rain (in $\mathrm{mm} /$ decade) is greater than the sum ETc2 ( $\mathrm{mm} /$ decade).

During the growth phase there is an increase in irrigation needs because we find that effective rainfall is lower than ETc2. For the mid-season and after-season phases, irrigation requirements are less important because we note a certain balance between actual rainfall and ETc2.

\section{Irrigation Schedule}

Year 2015 scenario A1B

Figure 9 shows the variation in the irrigation schedule as a function of the soil water retention capacity and the development of the crop. Here we take into account the readily available water (RAM) and the total available water (TAM). The water content is expressed as root depletion in this case.

Looking at the graph we find that the RAM and the TAM evolve with the capacity of retention of the soil. They increase with the water holding capacity until the 55th day after planting and then the TAM stays constant until harvesting contrary to the RAM which continues to increase from the 95 th. If we observe the exhaustion we see that it increases at a certain period (from the 25 th day to the 100th day after planting). This period corresponds to the time when a significant amount of precipitation falls.

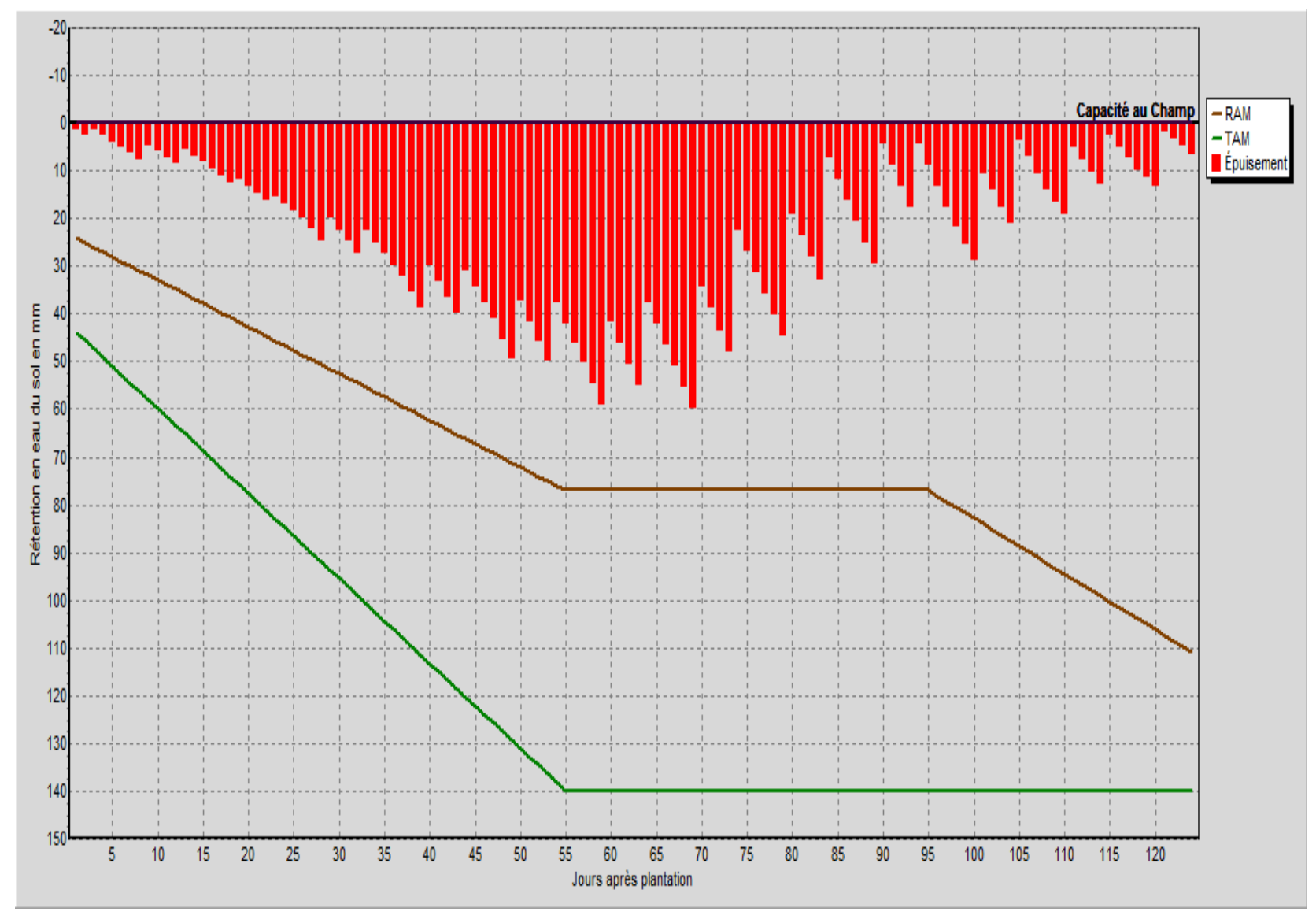

Figure 9. The irrigation schedule for the cultivation of maize for the year 2015 in scenario A1B 


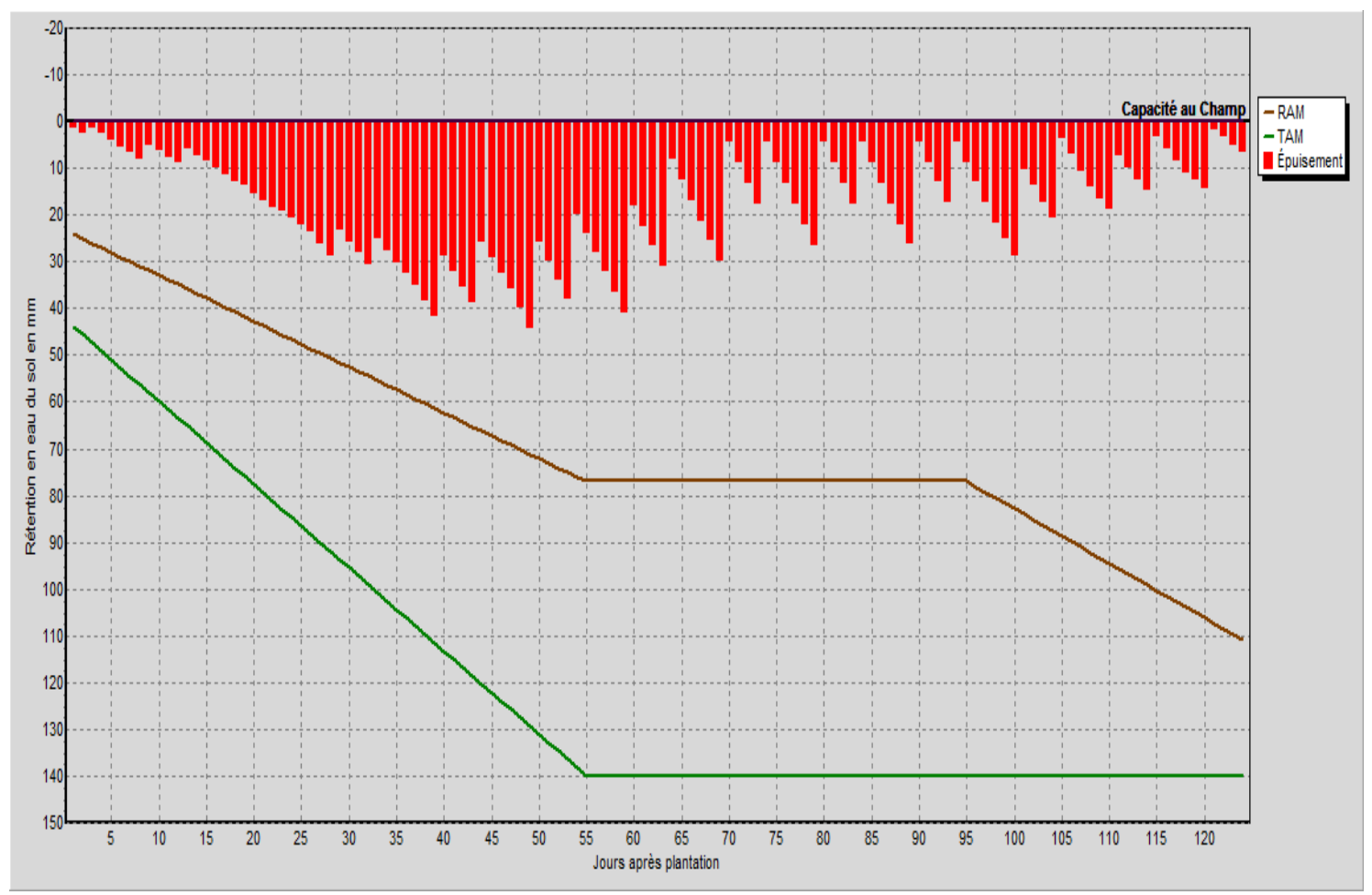

Figure 10. The irrigation schedule for the cultivation of maize for the year 2045 in scenarios A1B

\section{Projection 2045 scenario A1B}

Figure 10 shows the variation in irrigation scheduling for the year 2045. Unlike the previous graph, depletion increases earlier (from the 15th day) and is at a somewhat lower level. The variation of the RAM and TAM is identical to that of the year 2015. For this year we have a slightly more balanced distribution of precipitation.

Agricultural Calendar

Table 11. Is the result of the prediction of the ECHAM-5 MODEL in scenario A1

\begin{tabular}{|c|c|c|}
\hline SAISON & MOIS & STADE \\
\hline $\mathrm{A}$ & SEPTEMBRE & semis \\
\hline & OCTOBRE & $1^{\text {ier }}$ sarclage \\
\hline & NOVEMBRE & \\
\hline & DECEMBRE & 2 iem sarclage et récolte \\
\hline & JANVIER & Préparation du sol \\
\hline & & \\
\hline & FEVRIER & semis \\
\hline & MARS & sarclages \\
\hline & AVRIL & sarclage \\
\hline & MAIS & récoltes \\
\hline
\end{tabular}

\section{Discussion of Results}

Climate change can affect agriculture in a variety of ways. Beyond certain temperature thresholds, agricultural yields may decrease, as the acceleration of the growth process is accompanied by lower grain production (william, 2008).

From this analysis, it appears that the climatic variables (mean maximum and minimum temperatures, and precipitation) will show significant variations in its distribution according to the scenarios over the next thirty years: 2015-2045 as the ECHA- 5 compared to local station results.

According to Germain, 1952 The rainy season stretched from October to May and the dry season from June to September earlier (cf precipitation of local stations), also according to surveys conducted in 2010 (Mutalemba, 2010) the agricultural calendar Undergoes a strong change. Our results show that the rainy season in the Ruzizi plain should start in September but a fall in precipitation should be observed in October, the rainy month will be December to May. The sum Rainfall will vary from $100 \mathrm{~mm}$ in November to $178 \mathrm{~mm}$ in February for the ECHAM-5 model. The mean annual temperature in the plain of the RUZIZI was $24^{\circ} \mathrm{C}$, the maximum and minimum average temperatures reached $27^{\circ} \mathrm{C}$ and $30^{\circ} \mathrm{C}$ with an amplitude of $11^{\circ} \mathrm{C}$. Our study shows a variation of the maximum and minimum mean temperature between $19^{\circ} \mathrm{C}$ and $31^{\circ} \mathrm{C}$ for the ECHAM-5 model.

In recent years, however, some climate economists have tended to downplay them, even thinking that a few degrees Celsius may be beneficial to agriculture, but the increase in temperature also changes the ability of plants to retain and use moisture. The evaporation of the soil accelerates and the leaves of the plants lose more moisture, a double effect 
called "evapotranspiration". As global warming can cause more precipitation, the net impact of rising temperatures on water availability depends on the rate of increase in evapotranspiration and precipitation. In general, evapotranspiration is the fastest growing (william, 2008)

Precipitation will have to increase every year between 2015 and 2045 and will be spread over eight months over the whole year, from January to May and from September to the month Of December and over the entire period each year will be represented by four months which will be considered as dry season of June, July, August and November.

Maize is a demanding plant in light. It also has fairly high temperature requirements at germination. This is possible below $10^{\circ} \mathrm{C}$, fertilization is disturbed as soon as it exceeds $35^{\circ} \mathrm{C}$. (Depending on Guy, 1984). The decrease in temperature and the increase in altitude causes the elongation Of the vegetative cycle to produce a good yield maize requires a rainfall of 600 to $900 \mathrm{~mm}$ well distributed during the vegetation, it can adapt well to all the ecological conditions with an average temperature of $24^{\circ} \mathrm{C}$. Carbon, the main cause of climate change, can promote agriculture by improving the net photosynthesis of many important crops, "C3 plants" (wheat, rice, soybeans, etc.). However, scientists are far from certain of the benefits of fertilization due to carbon dioxide (carbon fertilization). On the other hand, it is not very useful for C4 crops (sugarcane, maize, etc.), which in value account for about a quarter of all crops (Nyabyenda, 2005).

As regards the agricultural calendar, we found that for the year 2015 the period from the 25 th day after planting to the 100th day will correspond to the maximum depletion period, this is due to the fact that this period corresponds to The one where we have a water deficit, hence the importance of irrigation. We have found that for the year 2045 the depletion of the root reserve will take place early but will be of less intensity if we consider the same date of Sowing than in 2015. The exhaustion decreases because in 2045 we have a large amount of Precipitation and a more or less balanced distribution.

These effects can be explained by the fact that the effects of climate change on agriculture result in a change in the distribution of rainfall, necessitating changes in the cropping calendar. Climate change will cause difficulties for farmers to locate their agricultural practices, as time indicators relating to the seasons have lost all reference.

\section{Conclusions}

Maize is a crop with High sensitivity to both water deficit and excess water. In sub-Saharan Africa, Particularly in Ruzizi are, there are several climate risks associated with temporal variability of rainfall, Season's parameters, to the resurgence of Phenomena such as heavy rains. All These factors, depending on the wintering profile,
May constitute a climatic constraint Maize productivity. The aim of this work is to determine the comparison in the prediction between the global models of atmospheric circulation and the regional and local model in order to evaluate the evolution of climatic parameters (temperature, Rainfall and radiation) and their impact on the agricultural calendar of maize and the availability of water for crops between 2015 and 2045. Thus, research was conducted using different meteorological Region considered the Ruzizi plain as a medium.

The model cham-5 is more adapted than other models presented in the work to the situation of the Ruzizi plain due to their adaptation to the data of the local weather stations. The model shows a strong variation of precipitation in During the year and allows to adjust the calendar, it presents 2 cropping season, among other things season A which begins in September until December, season $\mathrm{B}$ begins in February until month may. The calendar shows a fall in precipitation in October, which shows a shift in the date of sowing in maize.

\section{REFERENCES}

[1] Stern, P. and W. Easterling (eds), 1999: Making Climate Forecasts Matter: Report of the Panel on the Human Dimensions of Seasonal-to-Interannual Climate Variability

[2] Adams RM, Hurd BH, Lenhart S, Leary N (1998) Effects of global climate change on agriculture: an interpretative review. Climate Research, 11, 19-30.

[3] Adams RM, Rosenzweig C, Peart RM et al. (1990) Global climate change and US agriculture. Nature, 345, 219-224.

[4] Agrawala, S., K. Broad and D.H. Guston, 2001: Integrating climate forecasts and societal decision making: Challenges to an emergent boundary organization. Sci. Technol. Hum. Val., 26:454-477.

[5] Aguilar, a., aziz barry, a., brunet, m., ekang, 1., fernandes, a., massoukina, m., mbah, j., mhanda, a., do nascimento, d.j., peterson, t.c., thamba umba, o., tomou, m. \& zhang, x., 2009. Changes in temperature and precipitation extremes in western central africa, guinea conakry and zimbabwe, 1955-2006. journal of geophysical research, 114, do2115,

[6] ALLEN R., PEREIRA L., RAES, D. SMITH M., 1998: Crop evapotranspiration - Guidelines for computing crop water requirements - FAO Irrigation and drainage. Paper 56, FAO, Rome, 301 p.

[7] Arnold, S. 2010. Simulating impact of climate change in crop productivity using future climate projections and DSSAT crop simulation models. School of science and Management University of the Philippines Los Baños. College 4031, Laguna, Philippines. p19.

[8] Barry D. 2003. Contribution à la détermination des besoins en eau des principales cultures irriguées selon les zones agroclimatiques du Burkina Faso. Mémoire de fin d'études d’Ingénieur en Agrométéorologie, Centre Régional 
Agrhymet, Niamey, p. 56.

[9] Basu, S., 1953: Weather lore in India. Ind. J. Meteorol. Geophys., 4:3-12.

[10] Bruinsma J (2009) The Resource Outlook to 2050. By How Much do Land, Water and Crop Yields Need to Increase by 2050? FAO Expert Meeting on How to Feed the World in 2050. FAO, Rome.

[11] BUSH M. et FLENLEY J., 2007. Tropical rainforest responses to climatic change. Springer, 225 pages.

[12] DGPER. 2010. Analyse de la Compétitivité des Filières de Céréales Sèches au Burkina Faso. MAHRH Press: Ouagadougou.

[13] Diop M. 1996. À propos de la durée de la saison des pluies au Sénégal. Sécheresse, 7(1): 7-15.

[14] Diouf M, Nonguierma A, Abou A, Royer A, Somé B. 2000. Lutte contre la sécheresse au Sahel : acquis et perspective au Centre Régional Agrhymet. Sécheresse, 11(4): 257-266.

[15] Djerboua A, Duband D, Bois P. 2004. Estimations des lois des précipitations extrêmes à partir des données journalières complètes. La Houille Blanche, 3: 65-74

[16] Doorenbos J, Kassan AH. 1980. Réponse des rendements à l'eau. FAO, Bulletin d'irrigation et de Drainage 33, Rome.

[17] Doorenbos J, Kassan AH. 1980. Réponse des rendements à l'eau. FAO, Bulletin d'irrigation et de Drainage 33, Rome.

[18] DOORENBOS J., PRUITT W. O., 1977: FAO Irrigation and Drainage. Paper 24, Rome, $156 \mathrm{p}$.

[19] Fraisse, C.W., J.O. Paz, G. Hoogenboom, L.U. Hatch, A. Garcia y Garcia, L.C. Guerra and J.W. Jones, 2006: Peanut Irrigation Management Using Climate-based Information. St Joseph, ASAE

[20] Gerald C., 2009. Nelson,institut nationnal de recherche sur les politiques alimentaires, Changement climatique Impact sur l'agriculture et coûts de l'adaptation, Institut international de recherche sur les politiques alimentaires IFPRI Washington, D.C.

[21] Germain R., Rénee ghislain, Les associations végétales de la plaine de la Ruzizi en relation avec le milieu. Publ. Inéac, sér. Sci., 52, 321 pp. (1949). - Groupes nouveaux de Spermatophytes de la plaine de la Ruzizi. Bull. Jard. bol. Etal, Bruxelles, 22 : 373-377 (1952).

[22] Germain R.; 1952; Vallée dz la Ruzizi, note explicative des sols et de la végétation, Bruxelles .

[23] HOUGHTON, J.P., DING, Y., GRIGGS, D.J., NOGUER, M., VAN DER LINDEN, P.J., DAI, X., MASKELL,K. \& JOHNSON, C.A., 2001. Climate change 2001, The scientific Basis. Cambridge University Press, New York.

[24] Intergovernmental Panel on Climate Change (IPCC), 2001a. Climate Change 2001: The Scientific Basis. Working Group 1 Contribution to the IPCC Third Assessment Report. Online at http://www.ipcc.ch, November 2001.

[25] Intergovernmental Panel on Climate Change (IPCC), $2001 \mathrm{~b}$. The Regional Impacts of Climate Change: An Assessment of Vulnerability. Online at http://www.ipcc.ch, November 2001.
[26] IPCC (Intergovernmental Panel on Climate Change), 2007b. IPCC fourth assessment report: climate change 2007 (AR4). Available online at www.ipcc.ch/publications_and_data. Accessed on 15 December 2014.

[27] IPCC (Intergovernmental Panel on Climate Change), 2007c. IPCC fourth assessment report: Climate change 2007. Synthesis Report. p90.

[28] IPCC (Intergovernmental Panel on Climate Change), 2014b. Mitigation of climate change. Technical summary. Working group III. p65.

[29] Kambire H, Abdel-Rahman G, Bacyé B, Dembele Y. 2010. Modeling of Maize Yields in the South-Sudanian Zone of Burkina Faso - West Africa. AmericanEurasian J. Agric. Environ. Sci., 7(2): 195-201.

[30] KITAKYA, P., 2007. Interactions entre la gestion foncière et l'économie locale en région de Butembo, Nord Kivu, République Démocratique du Congo. Thèse de doctorat, Université catholique de Louvain.

[31] MAHÉ, G. L'HÔTE, Y., OLIVRY, J.C. \& WOLTING, G., 2001. Trends and discontinuities in regional rainfall of West and Central Africa - 1951-1989. Hydrological Sciences Journal, 46: 211-226.

[32] MALEZIEUX E., 2004. Agriculture du sud, foret tropical, effet de serre, volume inconnu;

[33] Mango, C., 1996.Structure de la population riveraines des chenaux de la ville d'Uvira (Sud-Kivu) et problème de son espace urbaine .Mémoire de fin d'étude, inédit ISP /Bukavu.

[34] Mashika, A., 1994.La maitrise des unités hydro-agricoles dans la plaine de la Ruzizi au sud-kivu /Zaire.Acteure, stratégie et en jeux. Mémoire de fin d'étude, inédit I.S.D.R/Bukavu :99pp.

[35] Nathaniel, B., G. 1998. Homogeneity, data adjustments and climatic normals. National Climatic Data Center. p18.

[36] Nathaniel, B., G. 1998. Homogeneity, data adjustments and climatic normals. National climatic data center. p18.

[37] NAVEAU, P., NOGAJ, M., AMMANN, C., YIOU, P., COOLEY, D. \& JOMELLI, V., 2005. Statistical methods for the analysis of climate extremes. C.R. Geosciences, 337: 1013-1022.

[38] New, m., hewiston, b., david, b., tsiga, s.a., kruger, a., manhinsue, a., gomez, b., coelho, c.a.s., masisi, d.n., kalulanga, e., bulane, e., fortunata, 1., mdoka, m.l.\& lajoie, r., 2006. evidence of trends in daily climate extremes over southern and west Africa. Journal of geophysical research, 111, d14102, doi:10.1029/2005jd006289.

[39] Nyabyenda pierre,2005 ;225p,32tabl.,32photos. ISBN 2-87016-072-0, Les plantes cultivées en régions tropicales d'altitude d'Afrique. T. 1. Légumineuses alimentaires. Plantes à tubercules et racines. Céréales

[40] OXFAM. 2009. The New Agriculturalist, accessed September 15, 2009, http://www.new-ag.info/en/focus/ focusItem.php? $\mathrm{a}=927$.

[41] OZER, P., BODART, C. \& TYCHON, B., 2005. Analyse climatique de la région de Gouré, Niger oriental: récentes modifications et impacts environnementaux. Cybergeo : Revue Européenne de Géographie. №.308, 02/05/2005, 24 
p. (http://www.cybergeo.presse.fr) consulté le 31 janvier 2013.

[42] Peterson, N.; and Broad, K. 2009. Climate and Weather Discourse in Anthropology: From Determinism to Uncertain Futures. In Anthropology and Climate Change: From Encounters to Actions, edited by S. A. Crate and M. Nuttall, pp. 70-86. California: Walnut Creek.

[43] Pindard A. 2000. La relation stress hydrique - rendement du maïs en Bresse : quelle perspective de spatialisation? Utilisation d'un simulateur de culture (STICS). Mémoire d'Ingénieur d'Agronomie, ENSA, Dijon, p. 86.

[44] Podesta, G.P., D. Letson, C. Messina, F. Royce, R.A. Ferreyra, J.W. Jones, J.W. Hansen, I. Llovet, M. Grondona and J.J. O'Brien, 2002: Use of ENSO-related climate information in agricultural decision making in Argentina: a pilot experience. Agric. Syst., 74:371-392.

[45] Poss R, Saragoni H, Imbernon J. 1988. Bilan hydrique simulé du maïs au Togo méridional. Agr. Trop., 43(1): $18-29$.

[46] Robelin M. 1963. Contribution à l'étude du comportement du maïs grain vis-à-vis de la sécheresse. In Journée internationale de l'irrigation, AGPM, Agen.

[47] Roncoli, C.; Ingram, K.; Jost, C.; and Kirshen, P. 2003. Meteorological Meanings: Farmers' Interpretation of Seasonal Rainfall Forecast in Burkina Faso. In Weather, Climate, Culture, edited by S. Strauss and B. Orlove, pp. 181-200. Oxford and New York: Berg.

[48] Sanou J. 1989. Etat de la Production du Maïs au Burkina Faso. Recommandations de la Recherche Agricole. INERA: Bobo Dioulasso.

[49] Sarr B, Ndjendole S, Diouf O, Diouf M, RoyMacauley H. 1999. Suivi de l'état hydrique du sol et de la température du couvert de maïs au Sénégal. Sécheresse, 10(2): 129-135.

[50] Sarr B, Ndjendole S, Diouf O, Diouf M, RoyMacauley H. 1999. Suivi de l'état hydrique du sol et de la température du couvert de maïs au Sénégal. Sécheresse, 10(2): 129-135.

[51] Sivakumar MVK. 1988. Predicting rainy season potential from the onset of rains in southern sahelian and sudanian climatic zones of West Africa. Agr For. Meteorol., 42: 295-305.
[52] SMITH M., ALLEN R., MONTEITH J.L., PERRIER L., PERRIER A., SEGEREN A., 1992: Report of the expert consultation on the procedures for revision of FAO Guidelines for prediction of crop water requirements. UNFAO, Rome, Italy, 54 p.

[53] SMITH M., ALLEN R., MONTEITH J.L., PERRIER L., PERRIER A., SEGEREN A., 1992: Report of the expert consultation on the procedures for revision of $\mathrm{FAO}$ Guidelines for prediction of crop water requirements. UNFAO, Rome, Italy, 54 p.

[54] SOLOMON, S., QIN, D., MANNING, M., CHEN, Z., MARQUIS, M., AVERYT, K.B., TIGNOR, M. \& MILLER, H.L., 2007. Climate change 2007. The physical sciences basis. Cambridge University Press, Cambridge, UK.

[55] William,R,cline, réchauffement climatique et agriculture, les effets de la sècheresse dans la sud-ouest de la Zambie, finance et développement mars 2008.

[56] Winarto, Y. T.; Fox, J. J.; Dwisatrio, B; Nurhaga, M.; Kinanti, N. Y. 2011a. Planthopper Virus Problems in Klaten, Boyolali, Sukoharjo, Indonesia, accessed August 21, 2011, http://ricehoppers.net/2011/08planthopper-virus-problems-i n-klaten-boyolali-and-sukoharjo-indonesia.

[57] Winarto, Y.T.; Fox, J.J.; Nurhaga, M.; Avessina, J.; Kinanti, N.Y.; and Dwisatrio, B. 2011b. Brown Planthopper in Klaten-Boyolali-Sukoharjo, Central Java, accessed May 18, 2011, http://ricehoppers.net/2011/05/ brown-planthopper-in klaten\%E2\%80\%94boyolali\%E2\%80\%94sukoharjo-central -java/. 2011c. Brown Planthopper Infestations in Lamongan, East Java, accessed June 13, 2011, http://ricehoppers.net/.

[58] WMO (World Meteorological Organization), 2010. Guide to agricultural meteorological practices. Weather, climate, water. WMO-No. 134. World Meteorological Organization. p799.

[59] WMO (World Meteorological Organization), 2014. Press release No. 997.30-year climate baselines to keep pace with rapid climate change. Available online: //www.wmo.int/pages/mediacentre/press_releases/pr_997_ en.html. Accessed on 12 November 2014.

[60] Xuebin, Z. and Feng, Y. 2004. RClimDex (1.0) User manual. Climate research branch Environment Canada downsview. Canada. p23. 